University of Nebraska - Lincoln

DigitalCommons@University of Nebraska - Lincoln

Agronomy \& Horticulture -- Faculty Publications

Agronomy and Horticulture Department

1969

\title{
Physiological Significance of Internal Water Relations to Crop Yield
}

R. O. Slatyer

Australian National University, Canberra City, Australia

Follow this and additional works at: https://digitalcommons.unl.edu/agronomyfacpub

Part of the Plant Sciences Commons

Slatyer, R. O., "Physiological Significance of Internal Water Relations to Crop Yield" (1969). Agronomy \& Horticulture -- Faculty Publications. 186.

https://digitalcommons.unl.edu/agronomyfacpub/186

This Article is brought to you for free and open access by the Agronomy and Horticulture Department at DigitalCommons@University of Nebraska - Lincoln. It has been accepted for inclusion in Agronomy \& Horticulture -Faculty Publications by an authorized administrator of DigitalCommons@University of Nebraska - Lincoln. 
Published in Physiological Aspects of Crop Yield: Proceedings of a symposium sponsored by the University of Nebraska, the American Society of Agronomy, and the Crop Science Society of America, and held at the University of Nebraska, Lincoln, Nebr., January 20-24, 1969. Edited by Jerry D. Eastin, F. A. Haskins, C. Y. Sullivan, C. H. M. Van Bavel, and Richard C. Dinauer (Madison, Wisconsin: American Society of Agronomy \& Crop Science Society of America, 1969). Copyright (C) 1969 American Society of Agronomy \& Crop Science Society of America. Used by permission. 


\title{
4
}

\section{Physiological Significance of Internal Water Relations to Crop Yield}

\author{
R. O. SLATYER \\ Australian National University \\ Canberra City, Australia
}

\section{INTRODUCTION}

The overall effects of water deficits on crop yield are known to everybody. Moderate water deficiencies can result in stunting, distorted development, and much reduced crop yields, and prolonged drought can cause complete crop failure.

Despite these visible symptoms of deficiency, a clear and unambiguous statement as to the effect of deficits on crop yield is difficult to make, for a variety of reasons. Firstly, despite the importance of the phenomenon to agriculture in most of the food producing countries of the world, relatively little attention has been devoted to its water deficits. Secondly, and in part this is a reason for the relative lack of effort,plant water status is a highly dynamic parameter, strongly influenced by conditions in the soil and atmospheric microenvironment, and also regulated to different degrees in different situations and with different species, by physiological factors. It therefore constitutes a difficult parameter to examine experimentally. Thirdly, as is the case with most types of lesion, water deficits affect the growth and development of crops in many ways, both directly and indirectly. Consequently, it is frequently difficult to assign cause and effect relationships with confidence.

Partly because of these complications, perhaps only two valid generalizations can be made as a basis for this paper:

1) In most crops growth and development proceed completely unimpaired, and crop yield is maximal, only when high water status is maintained throughout the life of the crop.

2) The deleterious effects of water deficits are usually most pronounced in tissues and organs which are in stages of most rapid growth and development.

It follows from the second point that there are periods of growth when there is relatively greater or lesser sensitivity to water stress, 
as far as economic crop yield is concerned. To give some idea of the significance of this phenomenon, it need only be stated that with some crops it is a practice on farms to impose stress at certain growth stages with a view to influencing development and improving the economic (though not necessarily the maximum) yield. Clearly this example already gives causes for concern as to the validity of the first generalization!

\section{DEVELOPMENT OF INTERNAL WATER DEFICITS}

The phrase "internal water deficit" means that the water potential $(\Psi)$ of the cell, tissue, or organ under consideration has dropped below the reference value of zero potential, where it would be at equilibrium with pure, free water. At zero water potential, the individual cells are fully turgid; as the water potential drops, cell turgor pressure drops and, when the cell water potential reaches the level at which cell turgor pressure is zero, the cell is quite flaccid. A leaf containing cells at this level of water potential can be expected to be completely wilted as long as its structural characteristics permit wilting to occur.

It is often said that internal water deficits develop in plants because transpiration exceeds absorption. Although this statement is true, in the most general terms, the rate of absorption relative to that of transpiration is not the only factor affecting the internal water deficit. A proper understanding of the manner in which internal water deficits develop requires a more detailed examination of the diurnal and day-today changes which occur in transpiration, absorption, and soil and plant water potential, and the reasons for these changes.

The level of plant water potential, and hence of internal water deficit, is influenced by two main factors: (i) the level of the soil water potential, and (ii) the diurnal lag of absorption behind transpiration. In turn each of these factors is influenced by other factors, both environmental and physiological.

For absorption to occur a gradient of water potential must extend from soil to leaf. (Although, in various segments of the transpiration pathway, component potentials rather than the total water potential may control water transport, the generalization that flow is controlled by total water potential is acceptable for the purposes of this discussion.) It follows that as soil water content (and soil water potential) is progressively reduced during a period of rainless weather, there is a concomitant drop in the level of plant water potential. That is, plant water potential cannot be higher than soil water potential (except in the rare situation of absorption of atmospheric water by shoots of plants), hence there is a base level of plant water potential and internal water deficit which is limited by the level of soil water potential.

Superimposed on this base level is the additional water deficit, and plant water potential drop, associated with the daily rhythm of transpiration and absorption. At the beginning of each day transpiration initially removes water from the leaves, and reduces leaf water potential ( $\Psi_{\text {leaf }}$ ) below its dawn value, without compensating absorption. Although absorption commences as soon as potential gradients extend 


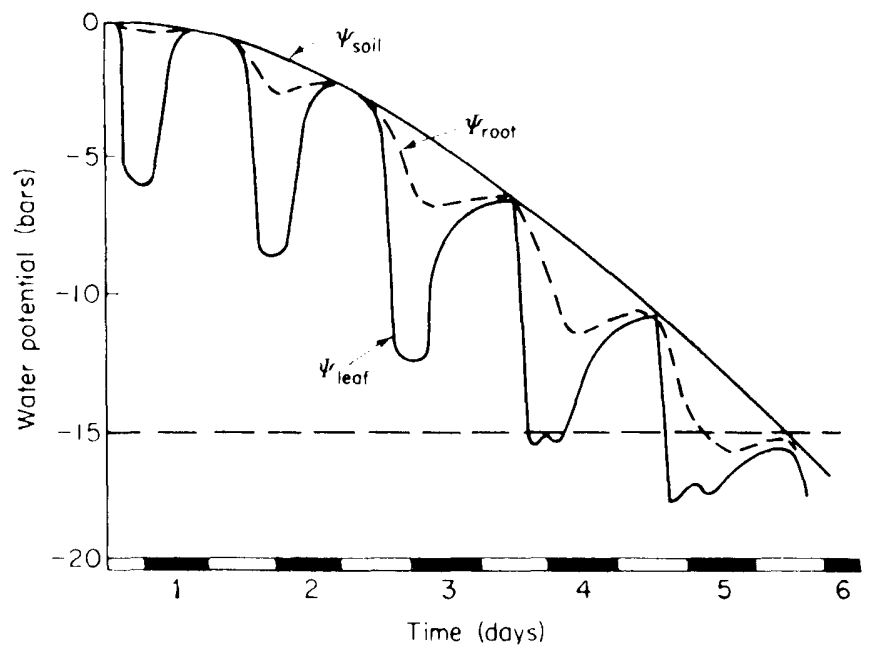

Fig. 4-1-Schematic representation of changes in leaf water potential $\left(\Psi_{\text {leaf }}\right)$, root surface water potential $\left(\Psi_{\text {root }}\right)$ and soil water potential $\left(\Psi_{\text {soil }}\right)$ as transpiration proceeds from a plant rooted in initially wet soil $\left.\left(\Psi_{\text {soil }}\right)=0\right)$. The same evaporative conditions are assumed to prevail each day. The horizontal dashed line indicates the value of $\Psi_{\text {leaf }}$ at which wilting occurs (from Slatyer, 1967).

down to and across the soil-root interface, the quantitative lag of total absorption behind total transpiration, and hence the magnitude of the internal water deficit, continues to increase until the rate of absorption equals the rate of transpiration and is only reduced when it becomes more rapid.

The interrelationships between these two phenomena are illustrated schematically in Fig. 4-1 from Slatyer (1967). Assuming that the same evaporation conditions prevail each day, the upper limiting curve shows the progressive decline in the water potential of the soil mass, $\Psi_{\text {Soil }}$, as the soil dries from an initially wet condition $\left(\Psi_{\text {Soil }}=0\right)$. The other curves show the water potential at the root surface, $\Psi_{\text {root }}$, and in the leaves, $\Psi$ leaf, assuming that transpiration proceeds for 12 hours and then ceases for 12 hours.

From the diagram, the progressive decline in soil water potential from day to day, which limits the level of plant water potential, and hence provides a lower limit for the internal water deficit, can clearly be seen. Also evident is the manner in which leaf and root water potential drop below this limiting value each day and tend to recover to the equilibrium value $\left(\Psi_{\text {soil }}=\Psi_{\text {root }}-\Psi_{\text {leaf }}\right)$ each night .

It can be seen that when the soil is wet (days 1,2 ), only small differences in $\left(\Psi_{\text {Soil }}-\Psi_{\text {root }}\right)$, i.e., small internal water deficits, are needed to sustain flow. As soon as transpiration falls in the evening there is a rapid recovery of $\Psi_{\text {plant }}$ and hence a rapid elimination of the diurnal water deficit. As $\Psi_{\text {Soil }}$ continues to fall, however (days 3,4 ), the hydraulic conductivity of the soil declines rapidly so that larger values of $\left(\Psi_{\text {soil }}-\Psi_{\text {root }}\right)$ are required to maintain flow at the desired 
level. By day 4 partial stomatal closure retards flow below potential levels, but even so recovery at night to the point where $\Psi_{\text {leaf }}=\Psi_{\text {soil }}$ becomes progressively slower.

As leaf water content and $\Psi_{\text {leaf }}$ decline, leaf cell turgor also declines and, depending on cell volume/turgor pressure relationships and the structural characteristics of the leaves concerned, they will gradually become wilted. There is good evidence that, in those leaves which do exhibit complete wilting, this occurs at the point when cell turgor pressure reaches zero (see Slatyer 1957a, 1957b; Gardner and Nieman, 1964).

Slatyer (1957a) proposed that at the point where $\Psi_{\text {leaf }}$ had dropped to a stage at which cell turgor pressure was zero, and when $\Psi_{\text {leaf }}=$ $\Psi_{\text {root }}=\Psi_{\text {Soil }}$, the plant would be in a state of permanent wilting and the soil water content would be the permanent wilting percentage. This point is indicated in Fig. 4-1 by the line drawn horizontally across the diagram at an arbitrary level of -15 bars, but it should be recalled that the actual soil water potentials at which permanent wilting occurs can vary over a wide range (Slatyer, 1957b).

Most physiological processes are affected by water deficits severe enough to cause permanent wilting. Some processes are sensitive to much smaller and more transient deficits. Clearly, transpiration, even in wet soil, cannot occur without the development of at least small water deficits, so it is virtually impossible to grow plants without some exposure to water stress. In the following discussion, most attention will be devoted to stresses which are severe enough to cause at least moderate wilting for short periods of time.

\section{EFFECTS OF WATER DEFICITS ON SOME PHYSIOLOGICAL PROCESSES}

The growth and development of a plant depends, in the simplest terms, on the progressive initiation of tissue and organ primordia and on the differentiation and expansion of the component cells until the characteristic form of the plant is realized. Associated with this phenomenon (basically genetically controlled) is an interconnected web of metabolic events which involve the uptake of nutrients from soil and air, the synthesis of metabolites and structural materials, and the transport of substances within the plant body.

Since all plant processes take place in what is effectively an aqueous medium, and since water is involved as a transporting agent or as a reactant in many of these processes, it is not surprising that reduced water uptake and dehydration can have deleterious effects on most physiological processes.

A consideration of the effect of water deficits on physiological processes cannot ignore the role of plant development in influencing the character of plant metabolism. Although reproductive development will be separately considered later in the paper, some general aspects of water deficits and plant development will be mentioned at this stage. 


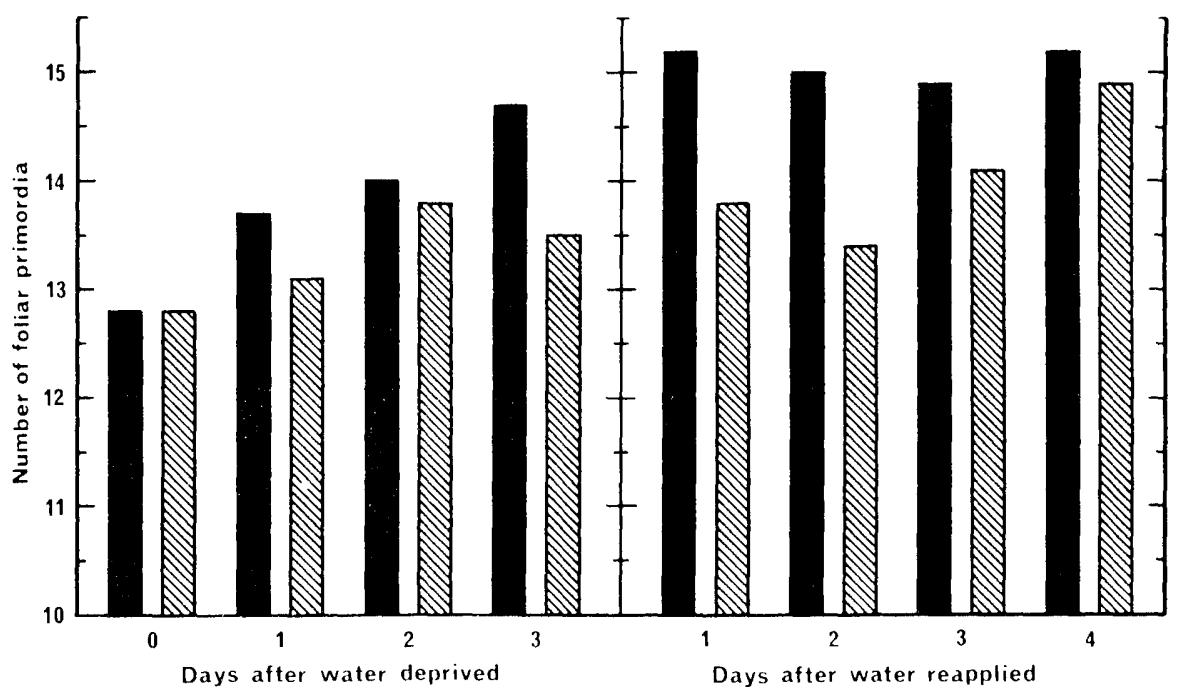

Fig. 4-2-Numbers of foliar primordia in Lupin apices during water deprival and upon rewatering (shaded columns) eompared with well watered controls (solid columns) (after Gates, 1968).

\section{A. Water Deficits and Growth Processes}

Both the initiation and differentiation of vegetative and reproductive primordia in the apical meristems, and the enlargement of the cells thus differentiated, are very sensitive to water stress.

The effect on primordial initiation appears to be superficially similar to that of dormancy, in the sense that initiation can be completely suspended without the potential for subsequent development being impaired, as long as the stress is not too severe or too protracted. Fig. 4-2 from Gates (1968) provides a good illustration of this point, using apical development of Lupin as experimental material. The virtual cessation of appearance of new primordia, as soon as stress was imposed,followed by renewed development upon relief of stress, is a phenomenon that has frequently been referred to in water stress literature (see for example Gates 1955a, 1968; Slatyer, 1967).

Cell division is also sensitive to stress, but the observation that leaves of plants which have undergone periods of stress may contain a similar number of cells to unstressed controls (Petinov; cited by Slatyer, 1965) suggests that the capacity for resumed activity upon relief of stress may remain unimpaired. As distinct from the situation with primordial initiation, however, where complete suspension may occur, cell division may continue during stress, though at a much reduced rate, until quite severe conditions exist (Gardner and Nieman, 1964). This provides the opportunity for a relatively rapid resumption of expansion growth when stress is removed. 
The renewed development upon re-watering often proceeds at a more rapid rate than in the controls, enabling stressed plants to "catch up." This phenomenon, evident in Fig. 4-2, has also been demonstrated on a field scale. Morton and Watson (1948), for example, showed that a crop of sugar beets (Beta vulgaris L.), subject to repeated cycles of water stress interspersed by irrigations, developed, overall, at the same rate as the well irrigated controls. Even so, where stress is more severe or is protracted, the rate of development can be markedly reduced, delayed flowering and maturation frequently being observed (Salter and Goode, 1967). In addition, the character of both vegetative and floral development can be seriously affected.

Cell enlargement, the other essential component of growth, is also affected at very slight stress levels. In fact, this is usually the first observable symptom of water deficits, and is a main cause of the stunting which is perhaps the most common sign of water stress under field conditions.

The main difference between the long-term effect of reduced rates of cell enlargement, and that of primordial initiation and cell division, is that cell enlargement is a plastic type of phenomenon, closely linked with the laying down of fairly rigid cell wall materials (Plaut and Ordin, 1964). In consequence, slower rates of enlargement are generally associated with smaller final cell size, so that "catching up," of the type referred to with regard to primordial initiation, is largely precluded.

In some species cell enlargement is so sensitive to water deficits that stem elongation or leaf enlargement can be inhibited by small diurnal water deficits that occur even with well watered plants on days of high radiation incidence (see for example Loomis, 1934). A more general response is one of a progressive decline in rates of cell enlargement as water deficits develop. Slatyer (1957a) suggested that rate of cell enlargement is more or less proportional to turgor pressure, but this is seldom a simple relationship (Lockhart, 1965) and enlargement may cease when turgor pressure levels are still at the level of several bars (Boyer, 1968).

Associated with these reduced rates of organ development and cell enlargement are many indirect effects on physiological processes, since nutrient inflow, and protein and carbohydrate synthesis and metabolism, are immediately affected by reduced developmental activity of cells and tissues. A key implication to final biological yield follows from the effect of reduction in cell expansion on total leaf area. This reduces the size of the photosynthesizing surface and can be expected to reduce crop growth rate unless leaf area is not limiting net assimilation rate.

The effect of water stress on the continued development of tissues which are already mature, or approaching maturity, resembles that of hastened senescence. One of the earliest signs of stress is the migration of phosphorus from older leaves to the stems and meristematic tissue (Williams and Shapter, 1955; Gates, 1957). This is closely followed by the movement of nitrogen, suggesting progressive protein hydrolysis and breakdown of normal cell function. Furthermore the stomata tend to remain closed and become nonfunctional (Slatyer and Bierhuizen, 1964).

Little is known of the effects of water deficits on root development. 
Although it is sometimes stated that root development is enhanced relative to shoot development during stress, there is little quantitative information on this point (Weaver, 1926; Troughton, 1962; Salim, Todd, and Schlehuber, 1965).

Two types of effects can be expected, the first being a reduction in rates of meristematic activity, and of root elongation, directly associated with the level of internal water deficit; the second, an effect of suberization on the water and nutrient uptake properties of the root system as a whole.

Most research has shown a progressive reduction in rate of root elongation as water stress is imposed (Salim, Todd, and Schlehuber, 1965; Newman, 1966) and, in some cases, root elongation ceases before shoot growth. In this regard Newman's (1966) work with flax (Linum usitatissimum L.) shows a high dependence of rate of root extension on local soil water potential. Thus roots in relatively moist soil may continue to elongate even though the plant as a whole is subject to severe internal water stress. In consequence continued exploration of the soil mass by root systems might be expected until the root zone is reduced to the same general level of water potential.

The effect of water stress on suberization can be expected to vary depending on the local rates of root extension. In rapidly growing roots a nonsuberized zone of $10-20 \mathrm{~cm}$ may occur in some species, constituting a highly active and extensive absorbing surface. As rates of root elongation are reduced the rate of suberization exceeds the rate of elongation, and the nonsuberized zone is reduced, until it is virtually eliminated in nonelongating roots. This phenomenon, common under conditions of severe water stress, substantially reduces the effective surface of the roots and their activity as absorbing organs.

In summary, it can be stated that the effect of stress on growth tends to be most pronounced in those tissues which are in rapid stages of development, a conclusion already reached by other workers (Williams and Shapter, 1955; Gates, 1968). Primordial initiation and cell enlargement are particularly susceptible. Although cell enlargement does not appear to compensate following the removal of stress, initiation does as long as the stress has not been too severe. The developing tissues appear to enter a rejuvenating phase on relief of stress. Relative growth rates of such plants may be more rapid than those of controls (Gates, 1955a, 1955b; Williams and Shapter, 1955). This rapid growth is aided by the continued, slow cell division which has occurred, and by the availability of nutrients released from older tissues.

\section{B. Water Deficits and Physiological Processes}

The effect of water stress on such key processes as nutrient uptake, carbohydrate and protein metabolism, and translocation of ions and metabolites is intimately linked with the effects on development since, as has been mentioned above, the rate of development affects both the supply and demand situation for many physiological processes.

For example, root development affects the size and character of the absorbing system for mineral nutrients; shoot development affects the rate of carbohydrate metabolism. The source strength represented 
by the size and activity of the photosynthetic system and the sink strength represented by tissue which requires carbohydrate, but which is not actively photosynthesizing, influences the rate of translocation.

However, direct effects of water stress on many key processes can be identified and some of these will now be considered.

\section{Water Deficits and Water Transport}

First of all, water stress directly affects water transport through the plant, and hence the rate of water absorption and transpiration. Under conditions of high soil water status, with only small gradients of water potential required for transport, the water potential drop in the leaves (needed to maintain high rates of flow) is relatively small and the stomata remain open. Transpiration is then primarily determined by environmental factors, particularly the amount of energy received by the plant and the factors which affect air flow around the leaves.

As soil water content falls, however, the water potential gradients required to move water to the roots and on to the leaves increase so that leaf water potential drops to levels which induce stomatal closure. Initially this phenomenon occurs for only a short period around midday. Commonly, transpiration is reduced to a level which enables absorption to exceed transpiration so that leaf water potential rises and the stomata generally re-open after a couple of hours. (This can also occur in well watered soils, when periods of excessive evaporative demand may cause marked reduction of leaf water potential.)

As soil water content continues to fall the period each day over which partial or complete stomatal closure occurs extends-the stomata closing earlier and re-opening later each day and acting as flow regulators to minimize dehydration.

The degree to which stomatal closure, in the light, is influenced by water deficits alone is beyond the scope of the present paper. However, it should be pointed out that Meidner and Mansfield (1965) have suggested that diurnal increase in leaf temperature may induce midday closure by increasing respiration rate and the level of intercellular $\mathrm{CO}_{2}$ concentration. The same phenomenon would tend to maintain closure until opening was induced by turgor recovery, or by photosynthetic depletion of intercellular $\mathrm{CO}_{2}$.

A direct consequence of stomatal closure is a tendency for reduced water uptake and transport, and for reducedgas exchange by the leaves, especially of water vapor and $\mathrm{CO}_{2}$. There is usually an increase in leaf temperature associated with a greater disposition of the absorbed energy into sensible heat transfer rather than evaporation. Perhaps the most significant effect is that on $\mathrm{CO}_{2}$ exchange which can directly regulate photosynthesis.

\section{Water Deficits and Nutrient Uptake}

The effect of water stress on mineral nutrition is difficult to resolve clearly. Although mineral nutrient uptake is frequently reduced to a considerable degree in stressed plants (Williams and Shapter, 1955; Greenway, Klepper, and Hughes, 1968), nutrient uptake is not directly 
Table 4-1-Absolute and relative amounts of nitrogen and phosphorus in the laminae and stems of severely stressed and unstressed tomate plants

\begin{tabular}{|c|c|c|c|c|c|c|c|c|}
\hline \multirow[b]{3}{*}{ Plant part } & \multicolumn{4}{|c|}{ Nitrogen } & \multicolumn{4}{|c|}{ Phosphorus } \\
\hline & \multicolumn{2}{|c|}{ Control } & \multicolumn{2}{|c|}{ Stress } & \multicolumn{2}{|c|}{ Control } & \multicolumn{2}{|c|}{ Stross } \\
\hline & $\begin{array}{l}\text { mg/ } \\
\text { plant }\end{array}$ & $\begin{array}{l}\% \text { dry } \\
\text { welght }\end{array}$ & $\begin{array}{l}\text { mg/ } \\
\text { plant }\end{array}$ & $\begin{array}{l}\text { y dry } \\
\text { weight }\end{array}$ & $\begin{array}{l}\mathrm{mg} / \\
\text { plant }\end{array}$ & $\begin{array}{l}\text { y.dry } \\
\text { weight }\end{array}$ & $\begin{array}{l}\text { mg/ } \\
\text { plant }\end{array}$ & $\begin{array}{l}\text { try } \\
\text { woight }\end{array}$ \\
\hline Laminac & 137 & 6.1 & 89 & $\overrightarrow{5} .4$ & 14.7 & 0.66 & 8.0 & 0. 49 \\
\hline Stem & 51 & 4,2 & 37 & 3.8 & 7.2 & 0.59 & 4.5 & 0.45 \\
\hline
\end{tabular}

* After (iates (1957).

dependent on water uptake (Russell and Barber, 1960) and soil nutrient availability, per se, is not necessarily affected by soil water stress (Wadleigh and Richards, 1951; Fawcett and Quirk, 1962) at least in the available soil water range.

Since the demand for nutrients also declines progressively, due both to the reduced rates of plant development and to the migration of nutrients out of older leaves, the key point is whether or not reduced nutrient uptake retards growth and development in a plant under stress.

Table 4-1 from Gates (1957) shows the absolute and relative levels of nitrogen and phosphorus in tomato plants (Lycopersicum esculentum Mill.) following "severe" stress. Although uptake of both elements was clearly depressed by the stress treatment, as shown by the absolute figures, the change in relative amounts is much smaller, and Gates does not comment on deficiency symptoms as such. A similar pattern emerged from a very comprehensive study of most nutrient ions (Williams and Shapter, 1955).

Although overall effects on nutrient content may not show marked changes, Gates (1957) has shown that the pattern can vary to a much greater degree when individual leaves are considered. In well watered plants, both nitrogen and phosphorus content decreased as leaf age increased. In stressed plants, nitrogen and phosphorus levels were also reduced, the younger leaves showing the greatest reduction, and phosphorus showing earlier and more pronounced reductions than nitrogen. With both nutrients there was a tendency for migration from leaf to stem as stress was imposed.

In summary it seems likely that nutrient supply may retard some aspects of growth and development during stress imposition. It is of interest to note that, upon re-watering, Gates observed a reversal of the above trends, with the preferential distribution of both nitrogen and phosphorus leading to greater uptake in the younger leaves. In the older leaves the senescence induced by stress was not completely reversed (see also Gates, 1968).

\section{Water Deficits, Protein Synthesis and Nitrogen Metabolism}

In general there appears to be a reasonably clear dependence of the growth rate of developing tissues and organs on protein synthesis, and a close association between protein synthesis and RNA (ribonucleic acid) content, and between RNA and DNA levels (deoxyribonucleic acid) 


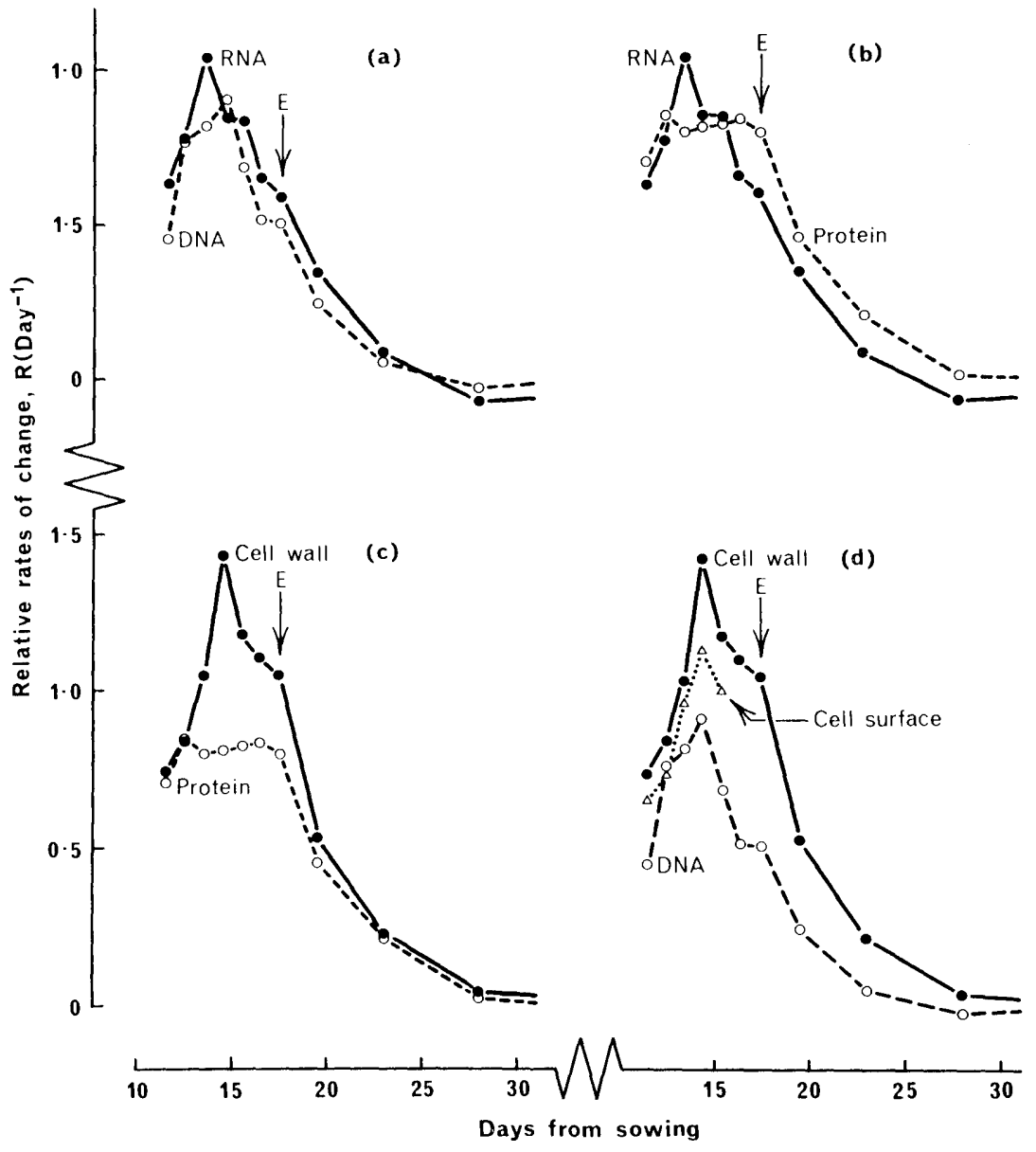

Fig. 4-3-Relative rates of change in various attributes of the fourth leaf of a wheat plant from initiation to maturation. $E$ is time of leaf emergence. (a) DNA and RNA, (b) RNA and protein nitrogen, (c) protein nitrogen and cell wall material, (d) $\mathrm{DNA}$, cell wall material and cell surface (from Williams and Rijven, 1965).

(see for example Woodstock and Skoog, 1960, 1962; Williams and Rijven, 1965). (Figure 4-3 from Williams and Rijven (1965) shows the nature of some of the associated phenomena for a developing wheat leaf (Triticum aestivum L.), although these authors are very cautious in the degree to which they associate any pair of these parameters, or assign cause and effect relationships.

From the known effects of water stress on rate of development, it can be expected that there will be associated effects on many aspects of protein synthesis. Indeed, interruption of protein synthesis and proteolysis are generally observed when stress is imposed (Zholkevich 


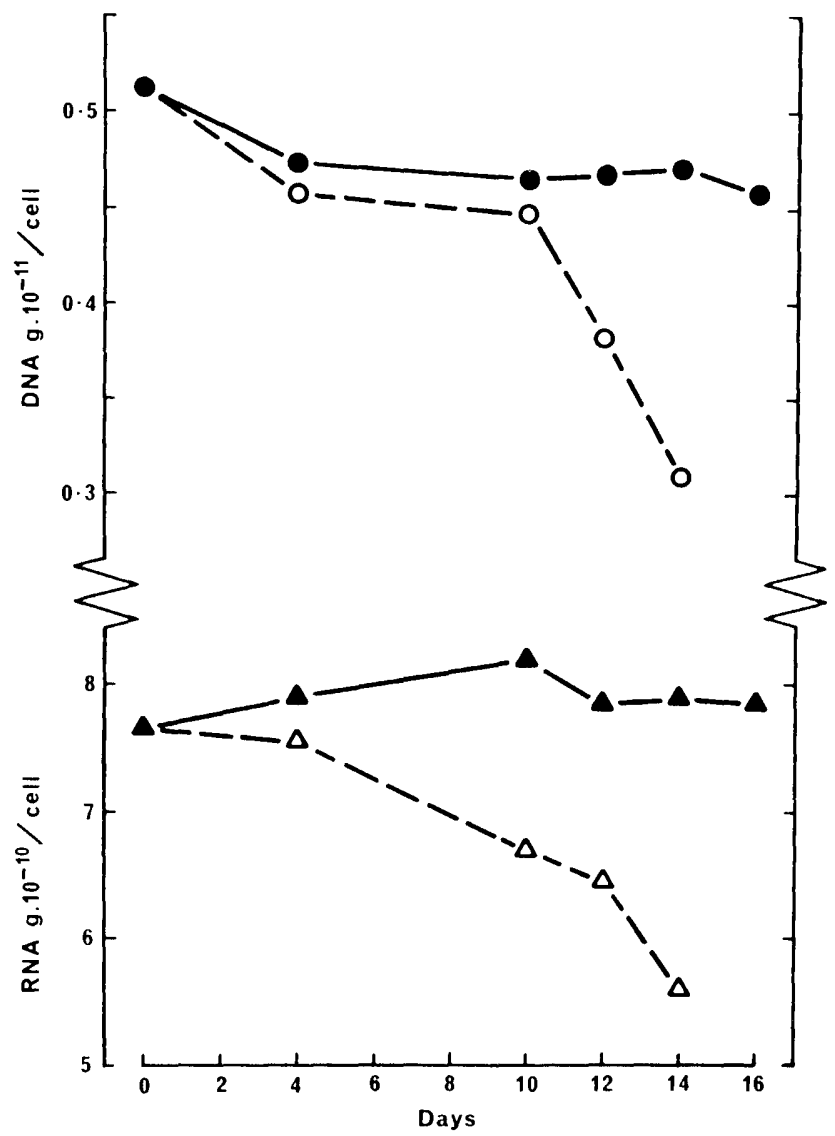

Fig. 4-4-DNA and RNA concentrations, expressed on a per cell basis, for stressed (dashed line) and unstressed (continuous line) sugar beet leaves. The progressive onset on stress caused wilting of the leaves from about day 10 onwards (after Shah and Loomis, 1965).

and Koretskaya, 1959; Chen, Kessler, and Monselise, 1964; Shah and Loomis, 1965; Ben-Zioni, Itai, and Vaadia, 1967).

Although few studies of the effects of water stress on nucleic acid metabolism have been made, the results form a fairly consistent pattern.

In the first place Shah and Loomis (1965) found a tendency for the DNA content per cell, which remained relatively constant with age in expanding beet leaves, to be reduced by water stress only if severe wilting occurred and was protracted (see Fig. 4-4). Gardner and Nieman (1964) showed a marked reduction of the rate of increase in DNA content of developing, and presumably actively dividing, cotyledonary leaves of radish at slight stress levels, but also found that there was still some increase in DNA level when severe stress was imposed. Together these results appear to be consistent with a marked sensitivity 
of cell division to stress, but with cell breakdown occurring only in developed tissues and under severe and prolonged stress conditions.

An effect on RNA levels (see also Fig. 4-4) tends to occur at lower stress levels and the ratio of RNA in stressed to that of unstressed leaves appears to decline progressively. Shah and Loomis (1965) concluded that RNA synthesis was impaired by stress and also that some degradation occurred in the RNA which was already formed when stress was imposed. A similar conclusion was reached by Zholkevich and Koretskaya (1959) with pumpkin roots (Cucurbita pepo). Gates and Bonner (1959) attributed the relative decline to enhanced degradation of RNA already formed rather than to impeded synthesis, because of evidence with $32 \mathrm{P}$-labelled RNA which showed that, while total RNA increased and total activity remained constant in the controls, total RNA remained constant in stressed plants and there was a progressive loss of label. They considered that the continued synthesis provided a base from which growth could be rapidly resumed upon rewatering.

The slightly different responses observed by these various workers is probably related in some degree to the developmental stage of the tissues with which they worked. A similar comment can probably be applied to the rather inconclusive results obtained to date by different workers as to the effect of water stress on the nucleotide composition of RNA (see for example Kessler, 1961; Shah and Loomis, 1965; West, 1966; Stutte and Todd, 1967).

The association between RNA and protein levels (see Fig. 4-3) was also found to be closely linked in stressed leaves, as shown in Fig. 4-5. On the assumption that ribosomal RNA plays a key role in protein synthesis, both Shah and Loomis (1965) and West (1966) examined the effect of stress on the level of ribosomal RNA, but no consistent pattern of change emerged from these studies, perhaps due to differences in treatments and to material studied. In beet leaves Shah and Loomis (1965) found a reduction in ribosomal RNA and a change in its nucleotide composition, with stress, whereas in corn seedling stems (Zea mays L.) West (1966) found an increase in ribosomal RNA and no change in composition. West did show, however, that polysome formation was slowed by stress and proposed that an effect of stress on messenger RNA could be a primary cause of reduced protein synthesis.

The changes reported previously in uptake and movement of nitrogen and phosphorus are consistent with the effects on nucleic acid and protein synthesis, suggesting that in expanding leaves the normal tendency to synthesize soluble nitrogen and phosphorus into more highly organized compounds was checked by water stress and that, especially in older leaves, hydrolytic breakdown processes tend to occur.

The role of certaingrowth substances, particularly auxins, gibberellins, and kinins, in retarding senescence, and the general similarity of many stress effects to processes associated with senescence, has provoked interest in the role of growth substances in water stress phenomena. In regard to protein synthesis, Richmond and Lang (1957) and Osborne (1965) have shown that the addition of cytokinins to the leaves of a number of annual plants has retarded chlorophyll degradation and has promoted amino acid incorporation and protein synthesis.

Recently Ben-Zioni, Itai, and Vaadia (1967) have examined the 


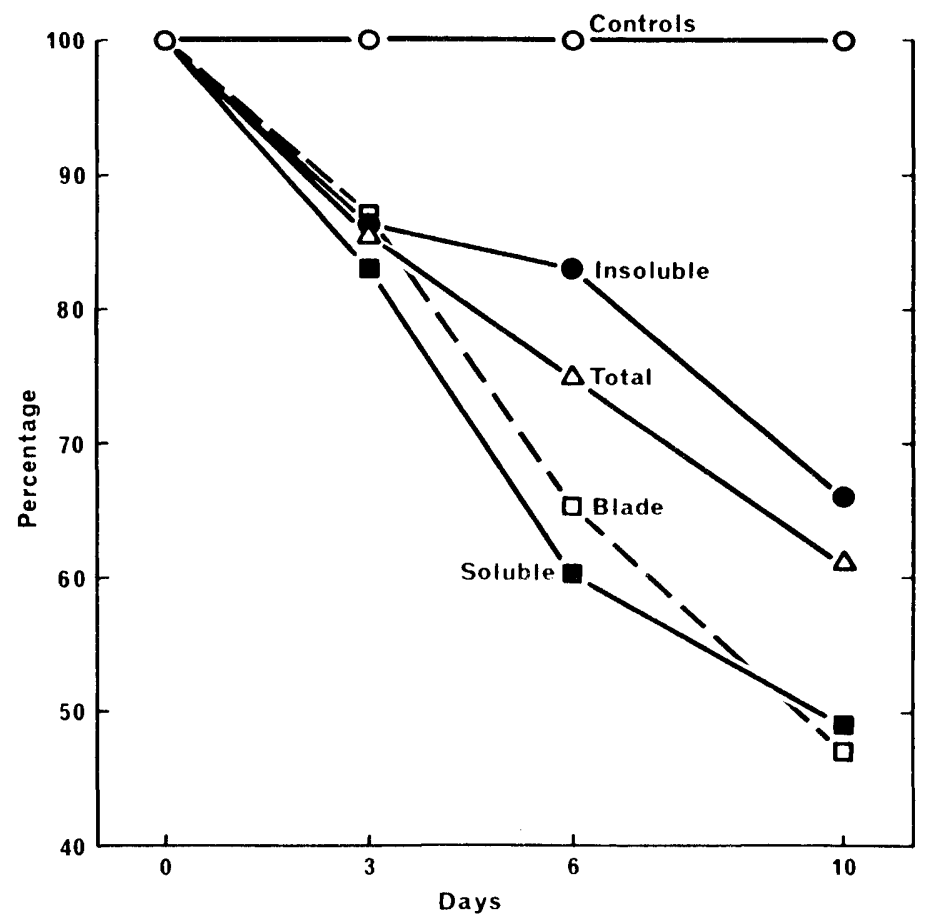

Fig. 4-5-Concentrations of total, soluble and insoluble RNA (continuous lines) and of leaf blade protein (dashed line) in leaves of stressed sugar beet plants, expressed relative to levels in non-stressed plants (after Shah and Loomis, 1965).

effect of kinetin in the incorporation of L-leucine in stressed tobacco leaves (Nicotiana tabacum L.). Even though the stress imposed was brief and mild (about -4 bars water potential), stressed tissues showed a marked reduction in ability to incorporate L-leucine into protein, the reduction being more pronounced in older than younger leaves. Stressed plants also had lower kinin levels in the root exudate, than did control plants.

The addition of kinetin restored incorporation in stressed leaves to levels approximating that of the controls, although a higher applied kinetin concentration was required to achieve this effect, compared with levels in control plants. (It should be noted that the kinetin was applied after stress; a greater effect may have followed its application prior to stress.) These workers are cautious in assigning a causal role for kinin level in protein synthesis, and point out that reductions in both kinin levels and protein synthesis could be merely reflections of disturbed metabolism. However, the known effects of kinins on rate of senescence suggests that kinin supply to the shoot is important in the maintenance of active protein synthesis, and also suggests that studies of root development and metabolism in relation to hormone balance may provide important insights into aspects of stress physiology.

A frequently observed effect of stress is the appearance of high 
levels of free amino acids, especially proline, and amides (Chen, Kessler, and Monselise, 1964; Kemple and Macpherson, 1954; Mothes, 1956; Prusakova, 1960). This phenomenon was recently investigated by Barnett and Naylor (1966) who found that although amino acids were continually synthesized during water stress in bermudagrass (Cynodon dactylon (L.) Pers.) protein synthesis was inhibited and protein levels decreased.

In their experiments water stress induced a marked increase in free proline, the $\mathrm{C}^{14}$ level of which turned over very slowly. Stressed shoots accumulated much more proline newly synthesized from glutamic acid than did control shoots. It was suggested that the slow turnover of labelled proline may reflect an inhibition of proline catabolism.

There is no clear understanding of the significance of this rise in proline level. However, Barnett and Naylor (1966) suggested that free proline may act as a storage compound for both carbon and nitrogen during water stress, when both starch and protein synthesis are inhibited. Such a storage pool might be utilized for renewed growth upon rewatering.

Various inhibitors have also been observed to influence development. Among them CCC (2 chloroethyltrimethylammonium chloride) (see, for example, Humphries, 1968) has created considerable interest and has been claimed to increase cereal yield under stress conditions. Humphries (1968) has reviewed the literature on this phenomenon and concluded that the primary effect of CCC is to increase root growth relative to shoot growth, thus delaying the onset of stress and reducing its severity. There may be a link between the role of $\mathrm{CCC}$ and that of kinin since the effects of CCC on root growth may influence the supply of kinins to the shoot, perhaps leading to stress tolerance.

\section{Water Deficits, Photosynthesis, and Carbohydrate Metabolism}

Carbohydrate metabolism can be affected in a number of ways by water deficits. There appear to be direct and indirect effects on photosynthesis, and on a number of intermediate components and processes.

In general, net photosynthesis is progressively reduced by water stress, and negative values may develop when stress is severe (ElSharkawy and Hesketh, 1964; Slatyer, 1967). It is assumed that this response is mediated partly by a way of impeded $\mathrm{CO}_{2}$ supply following stomatal closure and partly by a direct effect of dehydration on the photosynthetic system. Although many experiments have been conducted with a view to assessing the relative importance of stomatal closure and dehydration (see for example Crafts, 1968), they are of questionable value unless a quantitative measurement of the gas phase resistances to $\mathrm{CO}_{2}$ transport has been made, or treatments have been imposed which render this measurement unnecessary. In my opinion few such experiments have as yet been conducted.

One such study, conducted with cotton leaves (Gossypium hirsutum L.) (Troughton, 1969), has provided evidence that the observed reduction in net photosynthesis with increasing stress can be completely attributed to stomatal closure until quite severe stress exists. The type of 


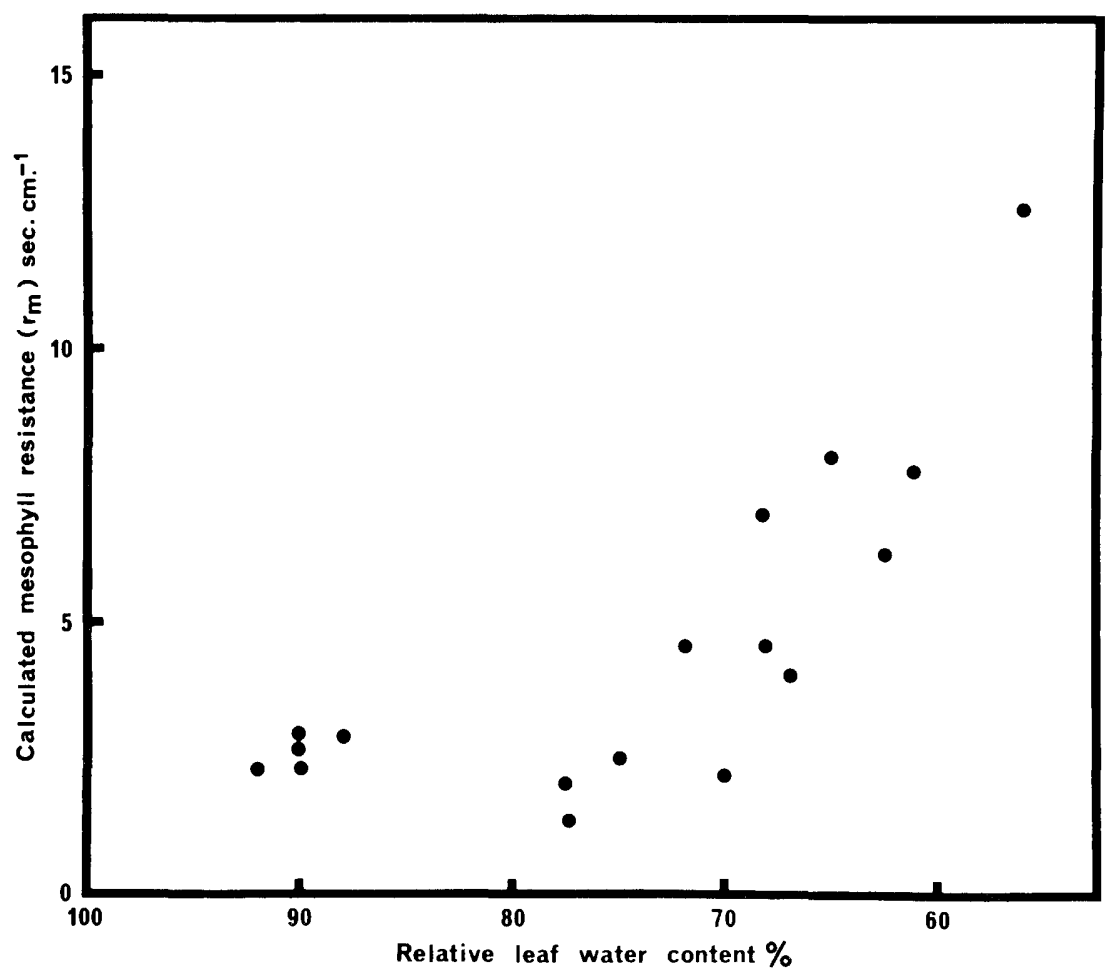

Fig. 4-6-Effect of water deficits on mesophyll resistance of cotton leaves (after Troughton, 1968).

evidence obtained is shown in Fig. 4-6 where the change in mesophyll resistance caused by reductions in relative water content is plotted. Mesophyll resistance is the slope of the curve relating $\mathrm{CO}_{2}$ concentration (between the mesophyll cell wall surfaces and the chloroplasts) to $\mathrm{CO}_{2}$ exchange. Any reduction in $\mathrm{CO}_{2}$ exchange, per unit of $\mathrm{CO}_{2}$ supplied, causes an increase in mesophyll resistance. It can be seen from Fig. 4-6 that there was no increase in mesophyll resistance in cotton leaves until relative water contents of about $75 \%$ were reached. Since cotton leaves wilt at relative water contents of around $80-85 \%$, severe stress, corresponding to leaf water potentials of the order of -20 bars, existed before direct effects of dehydration appeared.

Although other work suggests that mesophyll resistance may change at lower stress values (Meidner, 1961, 1962) it is not certain that stomatal or temperature effects were avoided. Assuming that generalizations can be drawn from Troughton's work, the results of Baker and Musgrave (1964) who showed reductions of net photosynthesis in corn of up to $40-50 \%$ at slight stress levels, may also be attributable to stomatal closure.

If progressive stomatal closure is the primary cause of the first stages of the photosynthetic response to water stress, there should be 
supporting evidence from other types of experiments which indicate that the photosynthetic apparatus, and the reactions associated with respiration, are relatively unaffected until severe water stress exists.

As far as the photosynthetic apparatus is concerned, the recent work of Santarius and colleagues (Santarius and Heber, 1967; Santarius and Ernst, 196?; Santarius, 1967) with isolated chloroplasts, and with leaf tissue segments, has provided evidence that such key processes in the photosynthetic reduction of $\mathrm{CO}_{2}$ as adenosine triphosphate (ATP) synthesis, the reduction of nicotinamide adenine dinucleotide phosphate (NADP) and the reduction of phosphoglyceric acid (PGA), were unafivted until very severe stress existed. In the leaf segments this corresponded to relative water contents of less than $50 \%$ (probably equivalent to water potentials below -25 bars). Although Santarius observed reductions in net photosynthesis, no attempt was made to control or assess stomatal effects or other aspects of the $\mathrm{CO}_{2}$ supply system; the key results, therefore, are those just reported.

Recent experiments by Troughton and Slatyer (1969) have also provided cvidence of the tolerance of gross photosynthesis to water deficits. In experiments in which photorespiration was suppressed by oxygenfree air, no effect on the mesophyll resistance of cotton leaves was observed even when relative water contents of $55 \%$ were imposed (equivalent to water potentials of about -50 bars). Since respiration was suppressed the experiment effectively demonstrated that gross photosynthesis was unaffected by stresses of this magnitude.

The effect of water deficits on respiration is somewhat obscure, partly because of the failure of many investigators to distinguish between dark respiration and photorespiration in those species in which the latter process is evident, partly because of the difficulties in measuring photorespiration, and partly because of possible differences in short term and long term effects.

With regard to dark respiration most recent studies have indicated that it is relatively unaffected by water deficits, until at least moderate water stress exists, and that a reduction rather than an increase is likely to occur. With Chlorella, for example, Greenway and Hiller (1967) found that water potentials of -10 bars did not affect respiration over periods of about 2 hours, although reductions were observed when the water potential was reduced to -20 bars. In short term (several minutes) experiments even water potentials of this level did not affect the uptake of acetate $2-{ }^{14} \mathrm{C}$ and also had little effect on the distribution or level of ${ }^{14} \mathrm{C}$ in the intermediates of the tricarboxylic acid (TCA) cycle, suggesting that there was no pronounced inhibition of respiratory pathways. In longer term (up to 56 hours) experiments with beet leaves, referred to above, Santarius (1967) found that dark respiration was not reduced until extremely severe stress (water potentials probably below -100 bars), existed.

The effect of water stress on photorespiration is difficult to assess because photosynthesis is proceeding at the same time. One index of an effect is a change in the $\mathrm{CO}_{2}$ compensation point and Meidner (1961, 1962) has measured increases in this parameter, as stress was imposed in several species, suggesting that photorespiration increases even at moderate stress levels. By comparison, Troughton and Slatyer 
(1969) did not ohserve a change in the CO compensation point of cotton 10ave war the stress enditions previously reported. A complicating

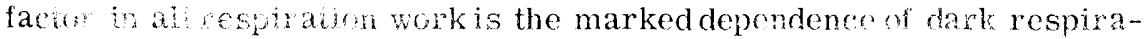
tion, and more porticularly photorespiration, on tempeature (Ze btch, 1967). Since stomatal closure generally induces an increase in leaf temperatue, indirect effects of water stress on net photosynthesis through this mans may outweigh direct effects of dehydration.

To summarize the preceding paragraphs, it can be stated that there is increasing evidence that stomatal closure, directly by impeding $\mathrm{CO}_{2}$ supply and indirectly by increasing leaf temperature, may be the primary mechanism by which water stress leads to reduced net photosynthesis under natural conditions. Much more work remains to be done however, before this matter is resolved.

Another factor which has been observed to influence photosynthesis is the availability of suitable sinks for assimilates. When utilization of assimilates is impeded, substantial reductions of net photosynthetic rate have been observed (see for example Burt, 1964: Nösberger and Humphries, 1965).

Again, the response pattern can be expected to vary between species. In species which can store significant amounts of assimilate as starch in the leaves, any effect can be expected to be much less than in species in which there is little starch storage, such as wheat. In wheat, King, Wardlaw, and Evans (1967) have shown dramatic and pronounced effects of sink size on photosynthesis, under nonstressed conditions.

During water stress, it appears quite probable that assimilates may be accumulated at sites of photosynthesis, since expansion growth is probably restricted sooner, and to a greater degree, than photosynthesis. Wardlaw $(1967,1969)$ examined this phenomenon in wheat and ryegrass (Lolium temulentum). He concluded that, although leaf photosynthesis was not affected until after growth rate had been reduced, there was no evidence of sink size directly affecting the rate of photosynthesis. However, he conceded that this interpretation could be revised, and that lack of suitable sinks could retard photosynthesis undor appropriate conditions.

Wardlaw $(1967,1969)$ also examined the translocation mechanism in these experiments. As Table 4-2 shows, he found that the velocity of assimilate movement in the conducting system wits not reduced, as

Table 4-2-.-klfeet of progressive water mires amposition in wherl during grain development on photosynthesis and velocity of tratslocation

\begin{tabular}{|c|c|c|c|}
\hline \multirow{2}{*}{$\begin{array}{c}\text { Days after } \\
\text { water } \\
\text { deprived }\end{array}$} & \multirow[b]{2}{*}{ Photosynthesis } & \multicolumn{2}{|c|}{ Velocity of assimilate movement } \\
\hline & & $\begin{array}{l}\text { Flag loaf } \\
\text { shoath }\end{array}$ & $\begin{array}{c}\text { Top } \\
\text { internode }\end{array}$ \\
\hline & $m g \mathrm{CO}_{2} \mathrm{dm}^{-2} \mathrm{hr}-1$ & $-+\cdots$ & 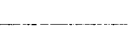 \\
\hline 0 & 12. 40 & 33 & 45 \\
\hline 2 & 13.25 & 42 & 36 \\
\hline 4 & 12.30 & 27 & 39 \\
\hline $6 \dagger$ & 7.15 & 39 & 72 \\
\hline
\end{tabular}

* After Wardlaw (1967). † Leaves wilted. 
long as adequate sink capacity existed, and concluded that the conducting system was remarkably resistant to water stress. Although these results conflicted with the conclusions of some other workers (Zholkevich, Prusakova, and Lizandr, 1958; Plaut and Reinhold, 1965; Hartt, 1967), which suggest a direct effect of stress on translocation, sink capacity may have been a factor in some of those experiments. The continued movement of assimilates from the green stems to the roots and buds in the perennial grass (Phalaris tuberosa) when the leaves had been shed during severe stress, indicates that the conducting tissue can be well maintained (McWilliams, 1968), even if the velocity of translocation is reduced.

Transport within the leaf does appear to be reduced by stress under some conditions. Although Plaut and Reinhold (1967) showed enhanced movement of ${ }^{14} \mathrm{C}$ applied to stressed bean leaves, Wardlaw's (1967) data and Hartt's (1967) experiments with sugarcane (Saccharum officinarum L.), show a greater retention of photosynthetic assimilates in wilted wheat leaves and a slower but prolonged movement of the assimilates out of the leaf. This result, however, may have been influenced by sink capacity because, in a subsequent experiment with perenial ryegrass, Wardlaw (1969) was able to maintain rates of movement out of stressed leaves, as long as adjacent actively photosynthesizing leaves were removed.

One of the most commonly reported effects of water deficits on carbohydrate metabolism is an increase in sucrose levels and decrease in starch levels (see for example, Iljin, 1957). These changes are frequently associated together, although there are reports of reduced polysaccharide levels not being accompanied by an increase in sugar content (Woodhams and Kozlowski, 1954).

Hiller and Greenway (1968) have recently examined more specific aspects of these phenomena in short term experiments with Chlorella. Their primary results were generally similar to those just described, water deficits (equivalent to water potentials down to -10 bars) causing a marked increase in sucrose synthesis, as measured by incorporation of applied ${ }^{14} \mathrm{C}$-glucose into sucrose, and an immediate and pronounced suppression of polysaccharide synthesis. They also observed reduced ${ }^{14} \mathrm{C}$ incorporation into methanol soluble intermediates other than sucrose, which was more pronounced for sugar phosphates than for amino acids. Incorporation into uridine diphosphate glucose (UDPG) was depressed more than that into hexose monophosphates, especially when stress was not too severe. Generally similar reductions in sugar phosphate levels have been observed in stressed Trifolium subterraneum (Wilson and Huffaker, 1964), and in starch formation in stressed sunflower (Helianthus annuus) (Plaut and Ordin, 1964).

The question arises as to the relationship between the enhanced sucrose and reduced polysaccharide levels. Reduced starch levels have been attributed to factors such as reduced photosynthesis and increased hydrolysis as well as to decreased synthesis (see for example, Mothes, 1956; Kozlowski, 1964). Although all these factors may operate, Hiller and Greenway (1968) found little evidence of hydrolysis, at least in the short term response to stress; similar levels of ${ }^{14} \mathrm{C}$ activity in methanolsoluble compounds being observed in stressed and unstressed cells 
which had previously been supplied with ${ }^{14} \mathrm{C}$-labelled bicarbonate in the light. They concluded that reduced starch formation was an indirect result of increased sucrose synthesis, rather than a direct effect of water stress on starch synthesis.

\section{EFFECT OF WATER STRESS ON GRAIN YIELD IN CEREALS}

In focussing the general effects of water stress on growth and development, on to the specific problem of grain formation and crop yield, there are three key stages to be considered. The first of these is the stage of floral initiation and inflorescence development when the potential grain number is determined. The second is the stage of anthesis and fertilization when the degree to which this potential is realized is fixed. The third is the stage of grain filling when grain weight progressively increases.

Although many aspects of yield development are common to all cereals, it is difficult to generalize widely as to the effects of water stress on grain yield, because of the considerable differences which do exist, in morphogenesis generally and reproductive development in particular, between various species. In the following discussion, data will be used to illustrate both similarities and differences in development patterns.

\section{A. Water Stress and Inflorescence Development}

Dealing first with the development of the inflorescence, there is good evidence that even slight water stress can reduce the rate of appearance of floral primordia. In Lupin, as depicted in Fig. 4-2, Gates (1968) has shown that this is one of the most sensitive reactions, and a similar pattern emerges with barley (Hordeum vulgare L.) (Nicholls and May, 1963) which is probably typical for most cereals. These studies suggest that if the stress is mild, and if the period of stress is relatively brief, rate of primordial initiation, upon relief of stress, is more rapid than in the controls and the total number of spikelets formed may be unaffected. On the other hand, if the stress is severe, or prolonged, total spikelet number may be substantially reduced.

Nicholls and May (1963) provided evidence that initiation of new primordia in the barley plant concludes with the appearance of stamen initials on the first formed spikelets. This is supported by the work of Williams (1966) on unstressed wheat plants. From their observations, Nicholls and May suggest that the number of spikelets per inflorescence is determined by the balance between the rate of primordial initiation relative to that of spikelet development. Since spikelet development appeared to be less affected by stress than primordial initiation, it follows that prolonged stress at the stage of floral initiation could markedly reduce the potential number of grains per ear.

An example of this effect is given in Fig. 4-7 where data from Nicholls and May (1963) are presented. The treatments consisted of a well watered control, and two water stress treatments. All treatments 


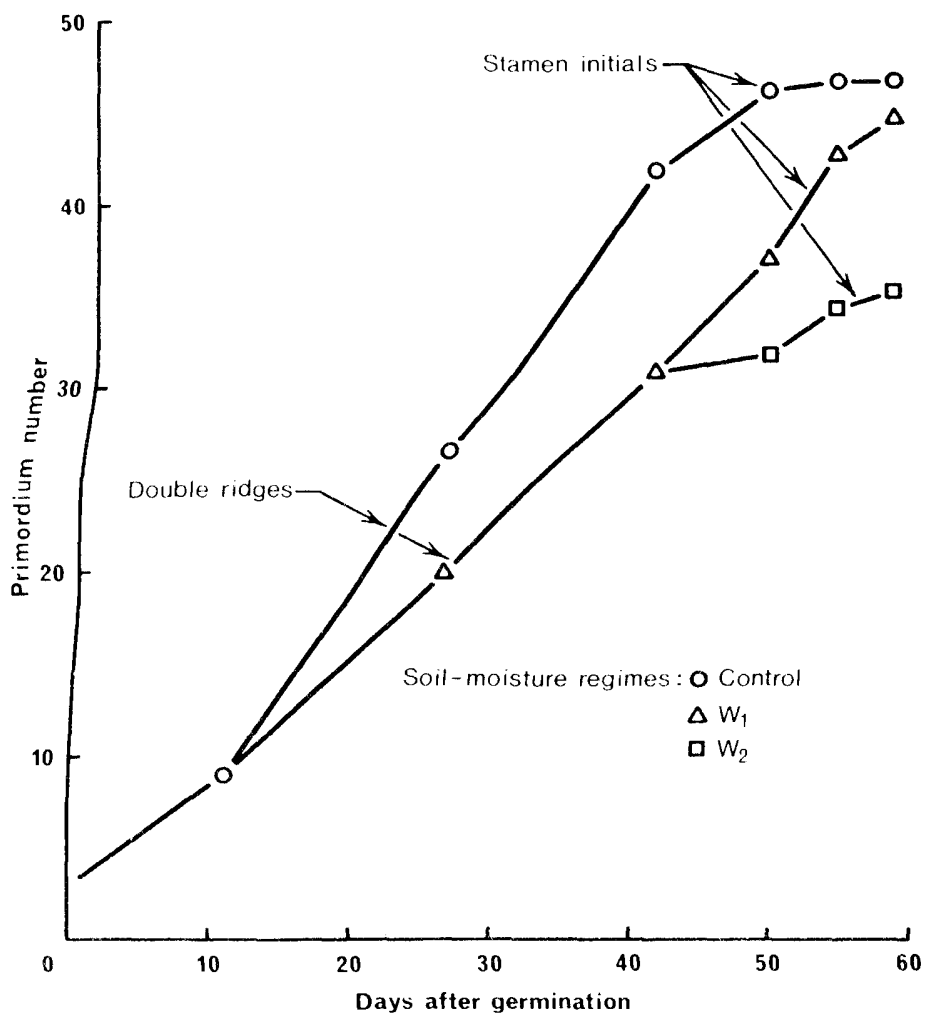

Fig. 1-7--Number of primordia formed in barley plants exposed to stress $(\Delta, \square)$ compared with well watered controls $(0)$. In the intermediate treatment $(\Delta)$ the plants were rewatered when soil water potential dropped to -5 bars (after Nicholls and May, 1963).

were well watered until about 10 days after germination. The first treatment was then deprived of water until the soil water potential dropped to -5 bars when it was rewatered, the second water stress treatment remained deprived of water (but soil water potential did not drop below - 15 bars).

Compared with the control plants, the rate of primordial formation in the plants deprived of water is seen to diverge almost immediately, so that the double ridges of the first spikelet primordia did not appear until several days after floral initiation commenced in the controls. (The total number of leaf primordia initiated was, however, the same in each treatment.) Rate of initiation of floral primordia became progressively slower in the stressed plants but, upon rewatering, the rate in the "mild" stress treatment increased rapidly so that, by the time of stamen initiation, total spikelet number was almost the same as in the controls. By comparison, in the "severe" stress treatment, total spikelet number was at a much lower level at the time when development of the spike was concluded.

Although this interpretation, if it could be generally applied, would 
provide a simple explanation of the effects of water stress on inflorescence development in cereals, the indeterminate character of the barley inflorescence may permit this type of response to a much greater degree than in species where the spike is determinate, and the rachis terminates in an apical spikelet. The explanation appears inadequate to account for the developmental patterns observed in grain sorghum (Sorghum vulgare Pers.), for example. In experiments in which the timing and duration of stress was varied around the stage of floral initiation, but in which all treatments constituted "severe" stress (wilted for 1 week or more), Whiteman and Wilson (1965) found that the development of the inflorescence could be suspended during stress yet could be resumed on rewatering and result in a flowering head not significantly different from that of control plants.

In one experiment, in which severe stress was imposed for periods of about 1 week, on three occasions during the normal time of floral initiation, initiation was totally suspended but was resumed upon rewatering. The time at which inflorescence development was completed was delayed for approximately 10 days, as was the time to commencement of flowering (see Table 4-3). There was no reduction in head size or yield.

In another experiment, stresses were imposed at about the stage of floral initiation and persisted for 14, 21, and 28 days. Floral initiation occurred in all treatments at about the same time as in the controls (stress not being fully effective at this stage), but there was no elongation of the inflorescence in the stressed plants until rewatering. From then on, development proceeded more or less at the same rate as in the controls and emergence of flowers took place at intervals of 10 , 24 , and 30 days after the controls, periods corresponding fairly closely to the durations of stress.

Although sorghum is known to be a drought tolerant crop, it seems probable that, as more data are collected, differences of a similar order may emerge between other common cereals. In corn, for example, Volodarski and Zinevich (1960) have claimed that a somewhat similar phenomenon occurs to that in sorghum, retardation of car initiation during stress being completely reversible. Unfortunately, the degree of stress imposed was not well defined and, if mild, the reversible response would be expected. However, evidence from Robins and Domingo

Table 4-3-kffect of water stress on loral initiation and time to llowering in sorghum

\begin{tabular}{ccc}
$\begin{array}{c}\text { Period of wiltingt } \\
\text { (days from sowing) }\end{array}$ & $\begin{array}{c}\text { Floral initiation } \\
\text { (days from sowing) }\end{array}$ & $\begin{array}{c}\text { Flowering } \\
\text { (days from sowing) }\end{array}$ \\
\hline Nil & $23-26$ & 58 \\
$15-21$ & $34-37$ & 68 \\
$19-25$ & $34-37$ & 68 \\
$27-35$ & $34-37$ & 65 \\
\hline
\end{tabular}

* After Whiteman and Wilson (1965).

+ Water was deprived well in advance of the appearance of wilting. In the last treat ment sufficient stress had presumably developed prior to wilting to prevent initiation from occurring at the same time as in the controls. 
(1953) and Denmead and Shaw (1960) that corn in the vegetative stage is relatively tolerant to stress, suggests that the indeterminate nature of corn ear development may lend itself to recovery of this type upon relief of stress.

From the state of spikelet initiation to fertilization of the ovules, a number of other processes, associated with the development of the inflorescence, are likely to be sensitive to water deficits, and thus cause a reduction in the number of grains per ear, or even in the number of fertile ears. Such effects have been reported in most cereals, for example in barley (Aspinall, Nicholls, and May, 1964; Skazkin and Zavadskaya, 1957; Wells and Dubetz, 1966); in oats (Avena sativa L.) (van de Paauw, 1949; Novikov, 1952, 1954; Skazkin and Lukomskaya, 1962); in wheat (Chinoy, 1962; Single, 1964; Bingham, 1967) and in corn (Robins and Domingo, 1953; Denmead and Shaw, 1960; Volodarski and Zinevich, 1960).

The effects have been attributed in some cases to specific interference with the sexual development of the spikelets, such as meiosis in the gametes (Skazkin and Lerman, 1952; Novikov, 1954; Skazkin and Zavadskaya, 1957; Bingham, 1967).

The availability of mineral nutrients and carbohydrates during the preflowering phase can also influence spikelet development, and may be an important means by which water stress effects are mediated.

Examples of this phenomenon are provided by the work of Single (1964) and Davidson (1965) with wheat. Single imposed a series of nitrogen treatments on wheat grown in. nutrient culture, which involved varying the nitrogen status from severely limiting to nonlimiting conditions at various stages of development. Nitrogen deficiency prior to spikelet initiation had a predictable marked effect on spikelet number and, if the nutrient level was not increased during the later development of the inflorescence, the number of fertile florets per spikelet did not exceed one. However, an increase in the nitrogen level, after spikelet initiation but before the appearance of the flag leaf, caused a markedincrease in the numeer of fertile florets and hence on final grain number.

In Davidson's experiment the leaves of the experimental plants were clipped to maintain leaf area indices (LAI's) at levels of 3 and 1 , compared with levels of up to 10 in control plants. The clipping treatments commenced after floral initiation, so did not affect the number of spikelets laid down, yet grain number per spikelet was reduced from 1.57 in the controls to 0.88 and 0.76 in the two treatments, respectively.

Although water stress was not imposed in these studies, photosynthesis, and hence the supply of assimilates, was markedly reduced by the treatments which were imposed. In Single's work the supply of nitrogen to the developing inflorescence was probably also reduced, in which case additional direct effects on protein synthesis and cell development could have occurred.

These results clearly indicate the importance of stress on the progressive development of the inflorescence prior to anthesis. In some plants such as wheat, the potential for variable floret numbers provides an opportunity for compensatory effects if stress is removed. This may also apply to oats but would not apply to crops such as rye, barley, or maize in which floret number is fixed (Bonnett, 1966). On the other 
hand, although this type of compensation may not occur, relief of stress in many species during the stage of inflorescence development may at least permit final grain number to approach the potential represented by the number of spikelets initiated.

The effect of water stress on the floral stimulus, that is, on the number of leaves formed prior to the commencement of floral initiation, has not been investigated in much detail although it is clear that the dramatic effects associated with photoperiod are not found with water stress effects. The most pronounced effects of which I am aware are those recently reported for tobacco by Hopkinson (1968). This work showed that water stress not only delayed floral initiation but that it took place at a higher node, differences of the order of 5 nodes being recorded.

In cereals there appears to be little evidence of pronounced shifts in the number of vegetative primordia prior to floral initiation. Nicholls and May (1963) showed that, in barley, stress imposed about 10 days beforefloral initiation did not affect the number of vegetative primordia iormed. Whiteman and Wilson (1965) with sorghum showed that as the date of onset of stress approached the normal time of floral initiation, mean leaf number could be reduced by up to 3 leaves. These workers considered that the leaf number at which floral initiation commenced may depend on the interaction between the amount of vegetative development necessary to allow the formation of a floral stimulus, and the extent to which stress may suspend development. With stress imposed well ahead of the normal time of floral initiation, there was insufficient vegetative development so that, on rewatering, leaf initiation was resumed.

By comparison, when stress was imposed closer to the normal time of floral initiation there had been sufficient vegetative development to permit the formation of a floral stimulus and, upon rewatering, floral initiation occurred at a lower leaf number. This explanation presumably requires the relatively higher leaf number, at which nonstressed plants flowered, to be influenced by a time factor which is relatively insensitive to stress, and which is associated with the passage of the floral stimulus from the leaves to the apex.

A frequently observed effect of water stress in the preflowering stage is a delay in date of flowering although some observations of advanced flowering have also been made (Salter and Goode, 1967). In sorghum, as has already been mentioned, the delay is closely related to the period of stress, but in other crops the relationship is less obvious. In wheat Chinoy (1960) showed that a period of 7 days wilting delayed anthesis by 8-18 days for eight varieties tested when applied at the preflowering stage. In this species, therefore, as compared with sorghum, post-stress development was less rapid than in control plants.

\section{B. Water Stress and Fertilization}

Stress at anthesis can markedly reduce fertilization and grain-set in most cereals. Perhaps the most sensitive crop, at this stage, appears to be corn (Robins and Domingo, 1953; Denmead and Shaw, 1960), 
Table 4-4-Effect of water regime on grain yield in corn

\begin{tabular}{lccc}
\hline \multicolumn{1}{c}{ Treatment } & \multicolumn{2}{c}{ Yield } & Shelling \\
\hline & $\mathrm{kg} / \mathrm{ha}$ & $(\mathrm{lb} / \mathrm{acre})$ & $\%$ \\
$\begin{array}{l}\text { Irrigated at anthesis, } \\
\text { plus 3 subs equent irrigations. }\end{array}$ & 9,294 & $(8,298)$ & 82.9 \\
$\begin{array}{l}\text { Irrigated at anthesis, } \\
\text { plus 2 subsequent irrigations }\end{array}$ & 8,930 & $(7,974)$ & 81.9 \\
$\begin{array}{l}\text { Irrigated at anthesis, } \\
\text { no subsequent irrigation }\end{array}$ & 6,384 & $(5,700)$ & 82.7 \\
$\begin{array}{l}\text { Wilted at anthesis, irigations } \\
\text { plus 2 subsequent irrigations }\end{array}$ & 5,315 & $(4,746)$ & 76.7 \\
$\begin{array}{l}\text { Wilted at anthesis, in } \\
\text { plus 1 subsequent irrigation }\end{array}$ & 4,482 & $(4,002)$ & 77.6 \\
\hline
\end{tabular}

* After Robins and Domingo (1953).

reductions of over $50 \%$ in yield being caused by relatively brief periods of wilting (see Table 4-4).

Since water stress frequently is associated with arid atmospheric conditions, it is sometimes suggested that stress at this stage acts by way of dehydration of pollen grains. However, it also seems probable that germination of the pollen, or growth of the pollen tube from the stigma to the ovules, may be impaired.

From the work of Robins and Domingo (1953) with corn, it appears that the latter explanation was the correct one in their experiments, since adequate amounts of pollen were available from well watered plants adjacent to stressed ones. It seems likely that if the styles are wilted the germination of the pollen or the growth of the pollen tube from the stigma to the ovules may be interfered with. This could be expected to be more pronounced in corn than in other cereals.

The relative sensitivity of different species to stress at the preflowering and flowering stages appear to vary somewhat, but comparable stress treatments have seldom been imposed and internal water deficits have seldom been measured, so detailed comparisons are impossible.

Species which flower over an extended period, usually because of the progressive flowering of tillers which develop after the main stem, are somewhat protected from isolated periods of stress. Some compensation also occurs if stress early in the vegetative period, which may interfere with spikelet development on the main stem, serves to promote tiller development. Although tillers may not have as many spikelets as a nonstressed main stem, the total number of grains per plant may be relatively little affected by a stress which severely reduces main stem grain number (see for example Aspinall, Nicholls, and May, 1964).

\section{Water Stress and Grain Filling}

The third component of grain yield-weight per grain-is influenced both by pre-flowering and post-flowering conditions. In almost all cases, however, the post-flowering stage is the more important. 
Yield development requires the accumulation of photosynthate in the grain. The two sources for these assimilates are photosynthesis in the ear itself and translocation from elsewhere in the plant. Although photosynthate accumulated prior to anthesis contributes to grain filling, and in some cases may provide a significant proportion of grain yield, by far the greatest contribution is usually from photosynthesis after anthesis by the ear, leaves, and stem (see for example Porter, Pal, and Martin, 1950; Thorne, 1963; Carr and Wardlaw, 1965; Allison and Watson, 1966). Figure 4-8, from Asana (1966), demonstrates this point in relation to wheat, showing that virtually all the increase in dry weight after anthesis is associated with grain filling. Clearly water stress, by reducing photosynthesis at this time, canlead to large yield decrements.

Although Wardlaw $(1967,1969)$ has shown fairly conclusively that there is little effect of water stress on translocation of assimilates in the conducting tissue itself, he has pointed out that translocation out of the leaves is slowed and prolonged by water stress. This phenomenon, combined with evidence that water stress hastens, rather than slows, maturation, and with the direct effect of stress on photosynthesis in the ear as well as in the leaves, contributes to lower grain weight in stressed plants.

Because grain filling is a relatively rapid process, because most of the increase in plant weight after anthesis involves grain development, and because it is a terminal process, it follows that the reduced photosynthesis at any point of the post-anthesis stage may have effects on grain weight which may not be compensated for by activity of other stages of grain filling (Aspinall, 1965).

On the other hand, there is also evidence that there may be an upper limit to grain size, and rate of grain filling, in any one phenotype

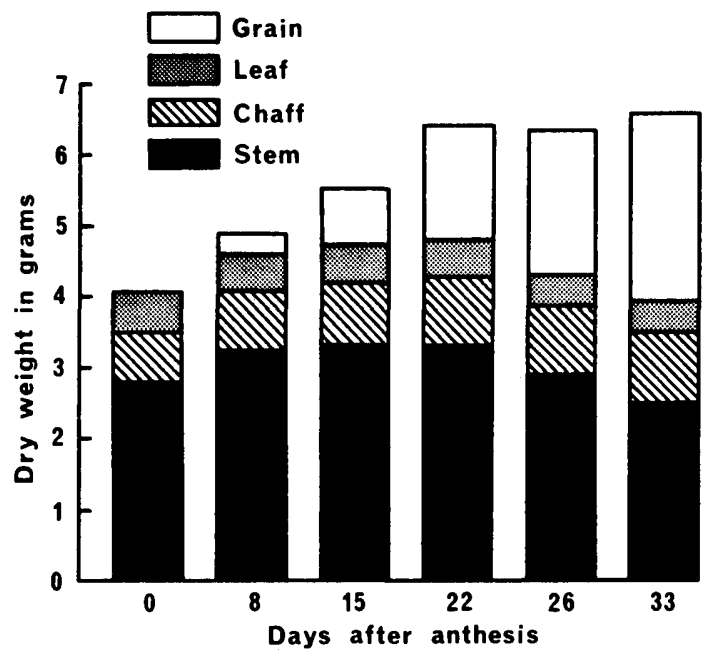

Fig. 4-8-Dry weight components of the tops of wheat plants from anthesis to maturity (after Asana, 1966). 
and that, in nonstressed plants, surplus photosynthate may be available. The work of Buttrose and May (1959) in which grain removal in barley did not lead to increased weight of the remaining grains is consistent with this view. It follows that a reduction in photosynthesis, caused by water stress, may not lead to reduced grain weight until any surplus photosynthate is eliminated. In this connection Asana and Basu (1963) showed that, for wheat, reduced photosynthesis caused by stress early in the grainfilling stage could be compensated for by enhanced translocation from the stem. They considered that, because of hastened senescence of leaves of stressed plants, stress occurring later in the grain filling stage could not be compensated for in this manner.

Prolonged stress throughout grain filling, even at moderate levels, almost invariably reduces grain weight (Salter and Goode, 1967). Fischer and Kohn (1966) have shown that wheat yield tends to be inversely correlated with the stress-induced rate of senescence of photosynthetic tissue after flowering. In some situations an enhanced gradient of grain weight from the base to the tip of the ear develops (Aspinall, 1965).

The relative importance of photosynthesis in the ear, the flag leaf, and elsewhere in grain filling does not appear to be a major factor in interpreting yield decrements under water stress conditions, even though it has been a subject of controversy for some time. There are, of course, important differences between species associated partly with crop morphology. For example, the role of ear photosynthesis is greater in wheat than in corn (Allison and Watson, 1966). In the presence of water stress, there is likely to be more rapid senescence of older leaves, which would lead to a flow of assimilates from them towards the ear, but would eliminate their continued role in supplying assimilates. Consequently the role of continued ear and flag leaf photosynthesis would become relatively greater.

\section{CONCLUSIONS}

It would be very satisfying if this paper could conclude with a succinct summary of the relative sensitivity of different growth and development stages, in different crops, to periods of water stress.

Unfortunately, it is difficult to draw such conclusions, not only because of inadequate knowledge, and because of differences between species, but also because compensatory effects can take place from one growth stage to another.

Overall it is apparent that, although maximum yield is likely to be obtained only if adequate water status is maintained throughout the life of cereal crops, mild or relatively brief stress can usually be completely compensated for by subsequent development under favorable conditions. In this regard the stage of inflorescence development appears to be the most adaptable, although this is true in some crops more than others. Anthesis is probably the least adaptable since it is such a brief yet important stage in the development of crop yield.

By comparison, severe stress, at almost any stage between floral initiation and maturity, is likely to result in marked yield decrements. 
Again it appears to be generally true that the preflowering stage is the most tolerant, but at anthesis and grain filling pronounced yield reductions are likely to be induced.

Two final remarks seem appropriate if they might stimulate research activity in this area. The first concerns the extent to which studies of morphogenesis have been linked to metabolism. It seems that too many studies have concentrated on either developmental or metabolic processes without sufficient emphasis on the link between the two. Environmental physiology can play a much more meaningful role in agronomy if physiological responses to stress are studied in relation to the stage of development at which they occur. The second concerns the problem of specification of the degree of stress in experimental treatments, a point already made by Kramer (1963). A reviewer is constantly thwarted by qualitative remarks as to the onset, duration and degree of stress imposed in various experiments. I encourage prospective investigators to pay more attention to means of inducing well-defined and reproducible levels of stress, and of monitoring them so that quantitative, and comparative, data can be obtained.

\section{ACKNOWLEDGMENT}

It is desired to acknowledge the valuable assistance of Dr. Nita Mortlock in preparing the bibliography on which this review was based.

\section{LITERATURE CITED}

Asana, R. D. 1966. Physiological analysis of yield of wheat in relation to waterstress and temperature. J. Indian Agricultural Research Institute Post-Grad. School 4:17-31.

Asana, R. D., and R. N. Basu. 1963. Studies in physiological analysis of yield. 6. Analysis of the effect of water stress on grain development in wheat. Indian J. Plant Physiol. 6:1-13.

Allison, J.C.S., and D.J. Watson. 1966. The production and distribution of dry matter in maize after flowering. Ann Bot. (N.S.)30:365-381.

Aspinall, D. 1965. The effects of soil moisture stress on the growth of barley: II. Grain growth. Aust. J. Agr. Res. 16:265-275.

Aspinall, D., P. B. Nicholls and L. H. May. 1964. The effects of soil moisture stress on the growth of barley: I. Vegetative development and grain yield. Aust. J. Agr. Res. 15:729-745.

Baker, D. N., and R. B. Musgrave. 1964. The effects of low level moisture stresses on the rate of apparent photosynthesis in corn. Crop Sci. 4:249-253.

Barnett, N. M., and A. W. Naylor. 1966. Amino acid and protein metabolism in Bermuda grass during water stress. Plant Physiol. (Lancaster) 41:12221230.

Ben-Zioni, A., C. Itai, and Y. Vaadia. 1967. Water and salt stressed, kinetin and protein synthesis in tobacco leaves. Plant Physiol. (Lancaster) $42: 361$ 365 .

Bingham, J. 1967. Investigations on the physiology of yield in winter wheat by comparisons of varieties and by artificial variation in grain number per ear. J. Agr. Sci. 68:411-422. 
Bonnett, O. T. 1966. Inflorescences of maize, wheat, rye, barley and oats: Their initiation and development. Illinois Agr. Exp. Sta. Bull. 721.

Boyer, J. S. 1968. Relationship of water potential to growth of leaves. Plant Physiol. (Lancaster) 43:1056-1062.

Buttrose, M. S., and L. H. May. 1959. Physiology of cereal grain: I. The source of carbon for the developing barley kernel. Aust. J. Biol. Sci. 12:40-52.

Burt, R. L. 1964. Carbohydrate utilization as a factor in plant growth. Aust. J. Biol. Sci. 17:867-877.

Carr, D. J., and I. F. Wardlaw. 1965. The supply of photosynthetic assimilates to the grain from the flag leaf and ear of wheat. Aust. J. Biol. Sci. 18:711-719.

Chen, D., B. Kessler and S. P. Monselise. 1964. Studies on water regime and nitrogen metabolism of citrus seedlings grown under water stress. Plant Physiol. (Lancaster) $39: 379-386$.

Chinoy, J. J. 1960. Physiology of drought resistance of wheat. I. Effect of wilting at different stages of growth on survival values of 8 varieties of wheat belonging to 7 species. Phyton 14:147-157.

Chinoy, J. J. 1962. Physiology of drought resistance of wheat. IV. Effect of wilting at different growth and developmental stages on plant characters determining yield of grain in 8 varieties of wheat. Phyton 19:5-10.

Crafts, A. S. 1968. Water deficits and physiological processes, p. 85-133. In T. T. Kozlowski (ed.). Water deficits and plant growth. Vol. 2. Academic Press, Inc., New York.

Davidson, J. L. 1965. Some effects of leaf area control on the yield of wheat. Aust. J. Agr. Res. 16:721-731.

Denmead, O. T., and R. H. Shaw. 1960. The effects of soil moisture stress at different stages of growth on the development and yield of corn. Agron. J. $52: 272-274$.

El-Sharkawy, M. A., and J. D. Hesketh. 1964. Effects of temperature and water deficit on leaf photosynthetic rates of different species. Crop Sci. 4:514-518.

Fawcett, R. G., and J. P. Quirk. 1962. The effect of soil water stress on the absorption of soil phosphorus by wheat plants. Aust. J. Agr. Res. 13:194-205.

Fischer, R. A., and G. D. Kohn. 1966. The relationship of grain yield to vegetative growth and post-flowering leaf area in the wheat crop under conditions of limited soil moisture. Aust. J. Agr. Res. 17:281-295.

Gardner, W. R., and R. H. Nieman. 1964. Lower limit of water availability to plants. Science 143:1460-1462.

Gates, C. T. 1955a. The response of the young tomato plant to a brief period of water shortage. I. The whole plant and its principal parts. Aust. J. Biol. Sci. $8: 196-214$.

Gates, C. T. 1955b. The response of the young tomato plant to a brief period of water shortage. II. The individual leaves. Aust. J. Biol. Sci. 8:215-230.

Gates, C. T. 1968. Water deficits and growth of herbaceous plants, p. 135-190. In T. T. Kozlowski (ed.). Water deficits and plant growth. Vol. 2. Academic Press, Inc., New York.

Gates, C. T., and J. Bonner. 1959. The response of the young tomato plant to a brief period of water shortage. IV. Effects of water stress on the ribonucleic acid metabolism of tomato leaves. Plant Physiol. (Lancaster) 34:49-55.

Gates, C. T. 1957. The response of the young tomato plant to a brief period of water shortage. III. Drifts in nitrogen and phosphorus. Aust. J. Biol. Sci. $10: 125-146$.

Greenway, H., and R. G. Hiller. 1967. Effects of low water potentials on respiration and on glucose and acetate uptake by Chlorella pyrenoidosa. Planta $75: 253-274$.

Greenway, H., Betty Klepper, and P. G. Hughes. 1968. Effects of low water potential on ion uptake and loss for excised roots. Planta 80:129-141.

Hartt, C. E. 1967. Effect of moisture supply upon translocation and storage of ${ }^{14} \mathrm{C}$ in sugar cane. Plant Physiol. (Lancaster) 42:338-346. 
Hiller, R. G., and H. Greenway. 1968. Effects of low water potentials on some aspects of carbohydrate metabolism in Chlorella pyrenoidosa. Planta 78:4959.

Hopkinson, J. M. 1968. Effects of early drought and transplanting on the subsequent development of the tobacco plant. Aust. J. Agr. Res. 19:47-57.

Humphries, E. C. 1968. CCC and cereals. Field Crop Abstr. 21:91-99.

Iljin, W. S. 1957. Drought resistance in plants and physiological processes. Ann. Rev. Plant Physiol. 8:257-274.

Kemble, A. R., and H. T. Macpherson. 1954. Liberation of amino acids in perennial ryegrass during wilting. Biochem. J. 58:46-50.

Kessler, B. 1961. Nucleic acids as factors in drought resistance of higher plants. Adv. Bot. 2:1153-1159.

King, R. W., I. F. Wardlaw, and L. T. Evans. 1967. Effect of assimilate utilization on photosynthetic rate in wheat. Planta 77:261-276.

Kozlowski, T. 1964. Water metabolism in plants. Harper and Row, New York.

Kramer, P. J. 1963. Water stress and plant growth. Agron. J. 55:31-35.

Lockhart, J. A. 1965. Cell extension, p. 826-849. In J. Bonner and J. E. Varner (eds.) Plant biochemistry. Academic Press, Inc., New York.

McWilliam, J. R. 1968. The nature of the perennial response in Mediterranean grasses. II. Senescence, summer dormancy and survival in Phalaris. Aust. J. Agr. Res. 19:397-409.

Meidner, H. 1961. The minimum intercellular space carbon dioxide concentration in leaves of the palm Phoenix reclinata. J. Exp. Bot. 12:409-413.

Meidner, $\mathrm{H}$. 1962. The minimum intercellular-space $\mathrm{CO}_{2}$-concentration $(\Gamma)$ of maize leaves and its influence on stomatal movements. J. Exp. Bot. 13:284293.

Meidner, H., and T. A. Mansfield. 1965. Stomatal responses to illumination. Biol. Rev. 40:483-509.

Morton, A. G., and D. J. Watson. 1948. A physiological study of leaf growth. Ann. Bot. (N.S.) 12:281-310.

Mothes, K. 1956. Der Einfluss des Wasserzustandes auf Fermentprozesse und Stoffumsatz. In W. Ruhland (ed.) Encyc. of Plant Physiol. 3:656-664.

Newman, E. L. $1 \overline{9} 66$. Relationship between root growth of flax (Linum usitatissimum) and soil water potential. New Phytol. 65:273-283.

Nicholis, P. B., and L. H. May. 1963. Studies on the growth of the barley apex. I. Interrelationships between primordium formation apex length, and spikelet development. Aust. J. Biol. Sci. 16:561-571.

Nösberger, J., and E. C. Humphries. 1965. Influence of removing tubers on dry matter production and net assimilation rate of potato plants. Ann. Bot. (N.S.) $29: 580-588$.

Novikov, V. P. 1952. The effect of a deficiency of water in the soil at different stages of development in oats. Dokl. Akad. Nauk. SSSR 82:641-643.

Novikov, V. P. 1954. Development of the oat panicle under different conditions of water supply. Bot. Z. 39:17-20.

Osborne, D. J. 1965. Interactions of hormonal substances in the growth and development of plants. J. Sci. Food Agr. 16:1-13.

Plaut, Z., and L. Ordin. 1964. The effect of moisture tension and nitrogen supply on cell wall metabolism of sunflower leaves. Physiol. Plant. 17:279-286.

Plaut, Z., and L. Reinhold. 1965. The effect of water stress on ${ }^{14} \mathrm{C}$ sucrose transport in bean plants. Aust. J. Biol. Sci. 18:1143-1155.

Plaut, Z., and L. Reinhold. 1967. The effect of water stress on the movement of ${ }^{14} \mathrm{C}$ sucrose and of triated water within the supply leaf of young bean plants. Aust. J. Biol. Sci. 20:297-308.

Porter, H. K., N. Pal, and R. V. Martin. 1950. Physiological studies in plant nutrition. XV. Assimilation of carbon by the ear of barley and its relation to the accumulation of dry matter in the grain. Ann. Bot. (N.S.) 14:55-68. 
Prusakova, L. D. 1960. Influence of water relations on typtophan synthesis and leaf growth in wheat. Fiziol. Rast. 7:139-48.

Richmond, A. E., and A. Lang. 1957. Effect of kinetin on protein content and survival of detached Xanthium leaves. Science 125:650-51.

Robins, J. S., and C. E. Domingo. 1953. Some effects of severe soil moisture deficits at specific growth stages in corn. Agron. J. 45:612-621.

Russell, R. S., and D. A. Barber. 1960. The relationship between salt uptake and the absorption of water by intact plants. Ann. Rev. Plant Physiol. 11:127-140.

Salim, M., G. W. Todd, and A. M. Schlehuber. 1965. Root development of wheat, oats, and barley under conditions of soil moisture stress. Agron. J. 57:603607.

Salter, P. J., and J. E. Goode. 1967. Crop responses to water at different stages of growth. Commonwealth Bureau of Horticulture and Plantation Crops, East Malling, Maid stone, Kent.

Santarius, K. A. 1967. Das Verhalten von $\mathrm{CO}_{2}-$ Assimilation, NADP-und PGS Reduktion and ATP-Synthese Intakter Blattzellen in Abhängigkeit vom Wassergehalt. Planta 73:228-242.

Santarius, K. A., and R. Ernst. 1967. Das Verhalten von Hill-Reaktion und photophosphorylierung isolierter Chloroplasten in Abhängigkeit vom Wassergehalt. I. Wasserentzug mittels konzentrierter Losungen. Planta 73:91-108.

Santarius, K. A., and U. Heber. 1967. Das Verhalten von Hill-Reaktion und Photophosphorylierung Isolierter Chloroplasten in Abhängigkeit vom Wassergehalt. II. Wasserentzug uber $\mathrm{CaCl}_{2}$. Planta 73:109-137.

Shah, C. B., and R. S. Loomis. 1965. Ribonucleic acid and protein metabolism in sugar beet during drought. Physiol. Plant. 18:240-254.

Single, W. V. 1964. The influence of nitrogen supply on the fertility of the wheat ear. Aust. J. Exp. Agr. Animal Husbandry 4:165-168.

Skazkin, F. D., and R. I. Leiman. 1952. Effects of a deficiency of soil water on vernalized and non-vernalized cereals in different periods of their development. C. R. Acad. Sci. U.S.S.R. 84:627-30.

Skazkin, F. D., and K. A. Lukomskaya. 1962. Characteristics of flowering in cereals in relation to the effects of soil moisture deficiency. Fiziol. Rast 9: 703-707.

Skazkin, F. D., and I. G. Zavadskaya. 1957. The effect of soil-moisture deficiency and nitrogen nutrition on microsporogenesis in barley plants. Dokl. Akad. Nauk. SSSR. 117:150-2.

Slatyer, R. O. 1957a. Significance of the permanent wilting percentage in studies of plant and soil water relations. Bot. Rev. 23:585-636.

Slatyer, R. O. $1957 \mathrm{~b}$. The influence of progressive increases in total soil moisture stress, on transpiration, growth, and internal water relationships of plants. Aust. J. Biol. Sci. 10:320-336.

Slatyer, R. O. 1965. The physiology of irrigated agricultural plants by N.S. Petinov. An abstract with commentary. Field Crop Abstr. 18:1-8.

Slatyer, R. O. 1957. Plant water relationships. Academic Press, London and New York.

Slatyer, R. O., and J. F. Bierhuizen. 1964. The influence of several transpiration suppressants on transpiration, photosynthesis, and water use efficiency of cotton leaves. Aust. J. Biol. Sci. 17:131-146.

Stutte, C. A., and G. W. Todd. 1967. Effects of water stress on soluble leaf proteins in Triticum aestivum L. Phyton 24:67-75.

Thorne, G. N. 1963. Varietal differences in photosynthesis of ears and leaves of barley. Ann. Bot. (N. S.) 27:155-174.

Troughton, A. 1962. The roots of temperate cereals. Comm. Bur. Pastures and Field Crops. Pub. 2.

Troughton, J. H. 1969. Plant water status and carbon dioxide exchange of cotton leaves. Aust. J. Biol. Sci. 22:289-302. 
Troughton, J. H., and R. O. Slatyer. 1969. Plant water status, leaf temperature and the calculated mesophyll resistance to $\mathrm{CO}_{2}$ of cotton leaves. Aust. J. Biol. Sci. 22: (in press).

Van der Paauw, F. 1949. Water relations of oats with special attention to the influence of periods of drought. Plant and Soil 1:303-341.

Volodarski, N. I. and L. V. Zinevich. 1960. Drought resistance of corn during ontogeny. Fiziol. Rast. 7:176-179.

Wadleigh, C. H., and L. A. Richards. 1951. Soil moisture and the mineral nutrition of plants, p. 411-450. In E. Truog (ed.) Mineral nutrition of plants. Univ. Wisconsin Press, Madison, Wis.

Wardlaw, I. F. 1967. The effect of water stress on translocation in relation to photosynthesis and growth. I. Effect during grain development in wheat. Aust. J. Biol. Sci. 20:25-39.

Wardlaw, I. F. 1969. The effect of water stress on translocation in relation to photosynthesis and growth. II. Effect during leaf development in Lolium temulentum L. Aust. J. Biol. Sci. 22:1-16.

Weaver, J. E. 1926. Root development of field crops. McGraw-Hill, New York.

Wells, S. A., and S. Dubetz. 1966. Reaction of barley varieties to soil water stress. Can. J. Plant Sci. 46:507-512.

West, S. H. 1966. Sub-cellular physiology as affected by drought. 10th Int. Grassland Congr. Helsinki:91-94.

Whiteman, P. C., and G. L. Wilson. 1965. The effects of water stress on the reproductive development of Sorghum vulgare Pers. Queensland Univ. Papers (Dept. of Botany) 4:233-239.

Williams, R. F. 1966. The physiology of growth in the wheat plant. III. Growth of the primary shoot and inflorescence. Aust. J. Biol. Sci. 19:949-966.

Williams, R. F., and A. H. G. C. Rijven. 1965. The physiology of growth in the wheat plant. II. Dynamics of leaf growth. Aust. J. Biol. Sci. 18:721-743.

Williams, R. F., and R. E. Shapter. 1955. A comparative study of growth and nutrition in barley and rye as affected by low-water treatment. Aust. J. Biol. Sci., 8:435-466.

Wilson, A. M., and R. C. Huffaker. 1964. Effects of moisture stress on acidsoluble phosphorus compounds in Trifolium subterraneum. Plant Physiol. (Lancaster) 39:555-560.

Woodhams, D. H., and T. T. Kozlowski. 1954. Effects of soil moisture stress on carbohydrate development and growth in plants. Amer. J. Bot. 41:316-320.

Woodstock, L. W., and F. Skoog. 1960. Relationships between growth rates and nucleic acid contents in the roots of inbred lines of corn. Amer. J. Bot. 47: 713-716.

Woodstock, L. W., and F. Skoog. 1962. Distributions of growth, nucleic acids, and nucleic-acid synthesis in seedling roots of Zea mays. Amer. J. Bot. 49: 623-633.

Zelitch, I. 1967. Water and $\mathrm{CO}_{2}$ transport in the photosynthetic process, p. 231248. In A. San Pietro, F. A. Greer, and T. J. Army (eds.) Harvesting the sun. Academic Press, Inc., New York.

Zholkevich, V. N., and T. F. Koretskaya. 1959. Metabolism of pumpkin roots during drought. Fiziol. Rast. 6:690-700.

Zholkevich, V. N., L. D. Prusakova, and A. A. Lizandr. 1958. Translocation of assimilates and respiration of conductive tissues in relation to soil moisture. Fiziol. Rast. 5:337-344. 


\section{$4 \ldots$ DISCUSSION}

PAUL J. KRAMER

Duke University

Durham, North Carolina

Professor Slatyer's paper emphasizes the fact that in spite of over 50 years of research we do not know cnough about the mechanisms by which water stress reduces the growth and yield of crop plants. It is not yet clear how much of the reduction is caused by effects of decreased turgor on cell enlargement and stomatal opening and how much results from direct interference with enzyme-mediated processes brought about by dehydration of the protoplasm. Perhaps modification of "sink" capacity by decreased cell division and enlargement in meristematic regions also is a major factor in the changes in carbohydrate and nitrogen metabolism observed in plants subjected to water stress. Furthermore, we do not know why some kinds of crop plants are more resistant to injury from water stress than others. Is it because they have better stomatal and cuticular control over transpiration, because they have more efficient root systems, or because their protoplasm is more resistant to dehydration? Lack of answers to these and similar questions is particularly embarrassing with respect to plant breeding and crop improvement programs because it is difficult to increase tolerance of drought until we know exactly how drought injures plants.

It is obvious that we need much more research in order to answer these questions. However, we should first ask ourselves why the great amount of research already done on the relationship between water supply and crop yields has not produced more satisfactory answers. I believe that Professor Slatyer has given you the reasons in the last paragraph of his paper and I wish to emphasize them.

The first reason is the common failure to measure plant water stress. The need for such measurements has been mentioned frequently during the past decade and satisfactory methods for measuring water potential and osmotic potential are available, but in too many instances the measurements have not been made. It therefore seems necessary to point out again that the only reliable method of evaluating plant water stress is by direct measurement on the experimental plants. I strongly urge that in all research involving plant water stress, quantitative measurements of plant water potential should be made.

The second reason that we do not have all the information that we should have is that the problem is very complex and our research of ten is too narrow in scope. We tend to study effects of water stress on only one or two processes at a time. As Professor Slatyer has said, we often study growth or metabolism, but not both simultaneously. Furthermore, we neglect to consider the stage of development, forgetting that a given degree of water stress produces quite different effects at dif- 
ferent stages of development. We need more comprehensive studies in which we measure plant growth, metabolism, and water stress, and simultaneously measure environmental factors such as soil water potential and rate of evaporation. In other words, we need to consider the entire soil-plant-atmosphere system.

If we keep these requirements in mind we can make our research much more productive and more useful to agriculture, horticulture, and forestry.

\title{
$4 \ldots$... DISCUSSION
}

\author{
J. J. OERTLI
}

University of California

Riverside, California

The correlations between water stress and plant responses, discussed by Dr. Slatyer, can be very useful in management practices but they do not-with few exceptions-permit any conclusions on the possible mechanism of operation of water stress since most of the plant responses must be secondary. Furthermore, neither the experiments described today, nor numerous others, give clearcut evidence that the total water potential is really the critical property to which plants respond.

This "critical property" deserves some discussion. Physical chemistry emphasizes the importance of the chemical potential as a criterion for the direction of spontaneous reactions. These concepts are applicable to the living system but one has to be careful to use a correct cell model. Water, in and around a cell, is usually close enough to equilibrium to permit writing the following equation of water potential:

$\Psi_{\mathrm{w}}=\Psi_{\text {cell }}=\Psi_{\text {vac }} \mathrm{P}^{+} \Psi_{\text {vac } \pi}=\Psi_{\text {prot }} \mathrm{P}+\Psi_{\text {prot } \mathrm{M}(+\pi)}=\Psi_{\text {org }} \mathrm{P}+\Psi_{\text {org } \pi}$

where $\mathrm{w}=$ cell wall; vac $=$ vacuole $;$ prot $=$ protein, referring to water of hydration on proteins; org = organelle; and P, $\pi, M=$ pressure, osmotic, and matric components. Suppose, for example, the turgor pressure is critical; in that case, a certain plant response is to be expected for a constant difference $\Psi_{\text {cell }}-\Psi_{\mathrm{vac}} \pi$, but the absolute value of the total and osmotic water potential can still vary widely. Thus, turgor pressure and total water potential do not necessarily change in the 
same direction. An example: Plants frequently respond to good fertilization by a disproportionate increase of the vacuolar osmotic pressure; because of this overadjustment, the turgor pressure ( $\Psi_{\mathrm{vac}} \mathrm{P}$ ), and with it the water content, increase whereas the total water potential $\Psi_{\text {cell decreases. }}$

Possible direct significance of potentials:

$$
\begin{aligned}
& \Psi_{\text {cell directly:questionable }} \\
& \Psi_{\text {vac } P} \approx \Psi_{\text {prot }} \text { P } \\
& \text { cell elongation, stomatal openings, }
\end{aligned}
$$
table.

Direct effects of solutes on metabolism are not considered in this

One may perhaps state that vacuolar cell water properties are determined by $\Psi_{\text {cell }}$, the solute content, and cell wall properties; the components $\Psi_{\mathrm{vac}} \mathrm{P}$ and $\Psi_{\mathrm{vac}} \pi$ adjust to these conditions but these components, especially $\Psi_{\mathrm{vac}} \mathrm{P}$ are physiologically more important.

The problem becomes more complex when we apply some of these concepts to irreversible cell elongation because now the dynamics of solute relations can become critical. Cell elongation requires an excess of internal pressure. The internal pressure can only be maintained at a certain level through continuous solute uptake. The quotient of the rate of solute uptake and the solute requirement is a measure for the 
rate of cell elongation. It can be shown for a simplified model (Oertli, 1968a) that

elongation rate (pressure constant $)=\frac{\text { rate of solute uptake }}{C\left(\Psi_{\sigma}+\Delta \Psi-\Psi_{\text {vac } P}\right)}$

where $C=$ constant, $\Psi_{\sigma}=$ soil water potential, and $\Delta \Psi=\Psi_{\text {cell }}-\Psi_{\sigma}$. For simplicity, let us restrict the discussion to osmotic moisture stress and to inorganic solute uptake. The rate of solute uptake (numerator) is now a hyperbolic function of the soil water potential. The solute requirement (denominator) increases linearly with soil moisture stress, starting from a finite requirement at $\Psi_{\sigma}=0$. As a consequence, cell elongation rates as a function of decreasing soil water potentials are first expected to increase, then to pass through an optimum and at more negative potentials to decrease again. This optimum can be demonstrated by experiments.

Let us now inspect the difference, $\Delta \Psi$, which depends on soil and atmospheric water potentials, on resistances in soils, plants, and atmosphere, and-usually not considered-on solute relations. Solute relations can be included in resistances if one so desires (Oertli, 1966). Here, I shall treat them separately.

1. Effects of atmospheric conditions:

Day: $\Delta \Psi$ very negative, elongation slow.

Night: $\Delta \Psi$ near zero, much elongation.

2. Effects of solutes:

Water in leaf transpires faster than solutes are taken up into leaf vacuoles, hence residual extracellular salt accumulation, hence, $\Delta \Psi$ more negative, hence cell elongation retarded.

Solute taken into leaf vacuoles faster than water loss through transpiration, hence $\Delta \Psi$ less negative or even positive, hence elongation accelerated.

This last case is interesting because it suggests that water can flow at a steady state against its free energy gradient. Thus, the soil water potential is not the upper limit for the plant water potential. One must realize that, for example, in a well-fertilized lawn, this situation can be observed almost every night.

I shall not discuss effects of resistance changes on $\Delta \Psi$ (wind, stomatal openings, wilting diseases, soil conductivity) nor shall I elaborate on the last term $\Psi_{\text {vac }} P$, which is really variable and where cell wall properties must be considered. These would add to the difficulty of describing the status of plant water by a single property, such as the total water potential. Another interesting aspect to discuss would have been the effect of increased respiration per unit elongation associated with the increased solute requirement.

My second comment concerns the currently popular view that water deficits (low $\Psi_{\text {cell }}$ ) generally develop because absorption lags behind transpiration. This statement is not entirely true, because the relation 
between water content and water potential is not unique, as I have demonstrated in the case of osmotic overadjustment. But even if this relation were unique, exceptions are possible. One example may suffice: Suppose the resistance to flow is increased markedly midway in the plant, e.g., in the petioles because of a wilting disease. If the water capacity effect before this resistance (in root and stem) exceeds the capacity effect after the resistance (leaf), then absorption exceeds transpiration. Nevertheless, leaves will wilt. In this case, the original statement, i.e., absorption lags behind transpiration, would be correct if only entry in and loss from leaves, were considered.

Finally, the terminology "absorption lags behind transpiration" has occasionally led to erroneous interpretations, e.g., that this is an indicator of resistances. The phenomenon is due to capacitance rather than to a prolonged transient state in conductive tissues. After a disturbance of a steady state, e.g., through a change of atmospheric relative humidity, a new steady state is approached rapidly in conduits (in uninterrupted vessels, pressure changes travel at a speed of nearly $1 \mathrm{mile} / \mathrm{sec}$ ). But cell water is no longer in equilibrium with the nearby transpiration stream and a movement of water is initiated. Thus, there is a multiplicity of sinks and sources, but I suspect that the system between sinks and sources is always close to the steady state. Naturally, as some of these sources become exhausted, new steady states are approached. Taking the viewpoint of cause and effect relations, it is not that water is lost from leaves because absorption lags; rather, absorption lags because water is lost from the leaf cells and the loss is due to an extracellular potential drop.

In summary, I have tried to raise questions as to how one might describe the state of plant water in a physiologically meaningful way; I have questioned generalizations about the direction of flow and free energy gradients, and about the development of plant moisture stress. Always, there are serious exceptions to rules which, at first sight, seem to be generally true. But such complications make the study of water relations more challenging and interesting.

\section{LITERATURE CITED}

Oertli. J. J. 1966. The significance of transpiration and various components of the water potential to plant behavior. Advance Front. Plant. Sci. 17:149-172.

Oertli, J. J. 1968a. The significance of the external water potential and of salt transport to water relations in plants. Int. Congr. Soil Sci. Trans. 9th (Adelaide, Australia). 1:95-107.

Oertli, J. J. 1968b. Effects of components of water potential on the water content of plant cells. Zeitschr. Pflanzenphysiol. 59:340-352. 